\title{
Mammalian target of rapamycin signaling and ubiquitin-proteasome-related gene expression in skeletal muscle of dairy cows with high or normal body condition score around calving
}

\author{
M. H. Ghaffari, ${ }^{1}$ K. Schuh,,${ }^{1,2}$ G. Dusel, ${ }^{2}$ D. Frieten, ${ }^{3}$ C. Koch, ${ }^{3}$ C. Prehn, ${ }^{4}$ J. Adamski, ${ }^{4,5,6,7}$ H. Sauerwein, ${ }^{1}$ \\ and H. Sadri ${ }^{8 *}+$ \\ ${ }^{1}$ Institute of Animal Science, Physiology and Hygiene Unit, University of Bonn, 53115 Bonn, Germany \\ ${ }^{2}$ Department of Life Sciences and Engineering, Animal Nutrition and Hygiene Unit, University of Applied Sciences Bingen, \\ 55411 Bingen am Rhein, Germany \\ ${ }^{3}$ Educational and Research Centre for Animal Husbandry, Hofgut Neumuehle, 67728 Muenchweiler an der Alsenz, Germany \\ ${ }^{4}$ Institute of Experimental Genetics, Genome Analysis Center, Helmholtz Zentrum München, German Research Center for Environmental Health, \\ 85764 Neuherberg, Germany \\ ${ }^{5}$ Lehrstuhl für Experimentelle Genetik, Technische Universität München, Freising-Weihenstephan 85350, Germany \\ ${ }^{6}$ German Center for Diabetes Research (DZD), München-Neuherberg 85764, Germany \\ ${ }^{7}$ Department of Biochemistry, Yong Loo Lin School of Medicine, National University of Singapore, Singapore 117597 \\ ${ }^{8}$ Department of Clinical Science, Faculty of Veterinary Medicine, University of Tabriz, 516616471 Tabriz, Iran
}

\section{ABSTRACT}

The objective of the current study was to investigate the effects of overconditioning around calving on gene expression of key components of the mammalian target of rapamycin (mTOR) pathway and ubiquitinproteasome system (UPS) in skeletal muscle as well as the AA profiles in both serum and muscle of periparturient cows. Fifteen weeks antepartum, 38 multiparous Holstein cows were allocated to either a high body condition group (HBCS; $\mathrm{n}=19$ ) or a normal body condition group (NBCS; $n=19$ ) and were fed different diets until dry-off ( $\mathrm{d}-49$ relative to calving) to amplify the difference. The groups were also stratified for comparable milk yields (NBCS: 10,361 $\pm 302 \mathrm{~kg}$; HBCS: $10,315 \pm 437 \mathrm{~kg}$ ). At dry-off, the NBCS cows (parity: $2.42 \pm 1.84$; body weight: $665 \pm 64 \mathrm{~kg}$ ) had a body condition score (BCS) $<3.5$ and backfat thickness (BFT) $<1.2 \mathrm{~cm}$, whereas the HBCS cows (parity: 3.37 \pm 1.67 ; body weight: $720 \pm 57 \mathrm{~kg}$ ) had a BCS $>3.75$ and BFT $>1.4 \mathrm{~cm}$. During the dry period and the subsequent lactation, both groups were fed identical diets but maintained the BCS and BFT differences. Blood samples and skeletal muscle biopsies (semitendinosus) were repeatedly ( $\mathrm{d}-49,+3,+21$, and +84 relative to calving) collected for assessing the concentrations of

Received June 19, 2019.

Accepted August 21, 2019.

*Corresponding author: sadri@tabrizu.ac.ir

$\dagger$ H. Sadri was a visiting scientist at the Institute of Animal Science, Physiology and Hygiene Unit, University of Bonn, 53115 Bonn, Germany, at the time the research was done. free AA and the mRNA abundance of various components of mTOR and UPS. The differences in BCS and BFT were maintained throughout the study. The circulating concentrations of most AA with the exception of Gly, Gln, Met, and Phe increased in early lactation in both groups. The serum concentrations of Ala (d +21 and +84$)$ and Orn $(\mathrm{d}+84)$ were lower in HBCS cows than in NBCS cows, but those of Gly, His, Leu, Val, Lys, Met, and Orn on d -49 and Ile on d +21 were greater in HBCS cows than in NBCS cows. The serum concentrations of 3-methylhistidine, creatinine, and 3-methylhistidine:creatinine ratio increased after calving $(\mathrm{d}+3)$ but did not differ between the groups. The muscle concentrations of all AA (except for Cys) remained unchanged over time and did not differ between groups. The muscle concentrations of Cys were greater on $\mathrm{d}-49$ but tended to be lower on $\mathrm{d}+21$ in HBCS cows than in NBCS cows. On d +21, mTOR and eukaryotic translation initiation factor $4 \mathrm{E}$ binding protein $1 \mathrm{mRNA}$ abundance was greater in HBCS cows than in NBCS cows, whereas ribosomal protein S6 kinase 1 was not different between the groups. The mRNA abundance of ubiquitin-activating enzyme 1 (d $+21)$, ubiquitin-conjugating enzyme $1(\mathrm{~d}+21)$, atrogin-1 $(\mathrm{d}+21)$, and ring finger protein-1 $(\mathrm{d}+3)$ enzymes was greater in HBCS cows than in NBCS cows, whereas ubiquitin-conjugating enzyme 2 was not different between the groups. The increased mRNA abundance of key components of mTOR signaling and of musclespecific ligases of HBCS cows may indicate a simultaneous activation of anabolic and catabolic processes and thus increased muscle protein turnover, likely as a part of the adaptive response to prevent excessive loss of skeletal muscle mass during early lactation. 
Key words: mammalian target of rapamycin, ubiquitin-proteasome system, body condition score, transition cow

\section{INTRODUCTION}

In dairy cows, the transition from late gestation to early lactation is associated with extensive changes in metabolic, endocrine, and immune functions (Drackley, 1999). In early lactation, dairy cows typically experience negative energy balance (NEB) because insufficient feed intake cannot support the increased nutrient demand for milk synthesis at the onset of lactation. Besides fat (de Vries and Veerkamp, 2000), mobilization of body protein reserves is also necessary to provide AA for milk protein synthesis, direct oxidation, or gluconeogenesis (Plaizier et al., 2000; Kuhla et al., 2011; Sadri et al., 2016). Reduced skeletal muscle protein mass and decreased diameter of the longissimus dorsi were demonstrated in dairy cows at the early stage of lactation compared with late stages (Phillips et al., 2003; Kessel et al., 2008). Body condition can influence the extent of protein mobilization in dairy cows at parturition and in early lactation. Cows that are overconditioned around calving have more severely depressed feed intake postpartum, leading to a more pronounced NEB, and subsequently they are more prone than moderately conditioned cows to develop a variety of metabolic abnormalities (Holtenius et al., 2003; Roche et al., 2009). Pires et al. (2013) reported that cows with low body condition (BCS $\leq 2.5$ ) mobilized less body fat but had more intense muscle protein catabolism during the first weeks of lactation compared with overconditioned cows (BCS $\geq 3.75$ ). The mechanisms underlying peripartum protein mobilization may be mediated by endocrine changes, including hypoinsulinemia and diminished muscle responsiveness to insulin, growth hormone, and IGF-1 concentrations (Bell et al., 2000), and the upregulated expression of components of proteolytic pathways in skeletal muscle (Chibisa et al., 2008). Cellular and molecular events, including the components involved in protein turnover signaling pathways, support the physiological and metabolic adaptations during the time of NEB when body fat and protein reserves are utilized to support lactation. Recent reports have demonstrated that the mammalian target of rapamycin (mTOR) pathway and the ubiquitin-proteasome system (UPS) were influenced in protein turnover of muscle and other body tissue in dairy cows (Castro et al., 2016; Sadri et al., 2016; Dong et al., 2018).

The loss of body protein in early lactation can range from 12 to $21 \mathrm{~kg}$ within the first 5 wk postpartum (Komaragiri and Erdman, 1997; Komaragiri et al.,
1998; Chibisa et al., 2008). Two distinct multiprotein complexes (mTORC1 and mTORC2) integrate multiple signals of satiety from AA abundance, hormones, and growth factors (Sheldon et al., 2017). The mTORC1 complex controls protein synthesis, cellular proliferation, cell size, and gene expression, whereas the mTORC2 complex regulates cytoskeleton formation in response to nutrients and growth factors (Jacinto et al., 2004). For protein degradation, the UPS is regarded as the central proteolytic pathway in the muscle (Rock et al., 1994). It requires the coordinated reactions of 3 enzymes, including E1 (an ubiquitin-activating enzyme), E2 (an ubiquitin-conjugating enzyme), and E3 (ubiquitin ligases; Schulman and Harper, 2009; David et al., 2010). The 2 muscle-specific E3 ubiquitin ligases [atrogin-1 and muscle ring finger protein-1 (MuRF1)] are specific markers of muscle wasting and are upregulated during muscle-wasting conditions (Franch and Price, 2005; Foletta et al., 2011). Greenwood et al. (2009) observed a 2.1-fold greater upregulation of ubiquitin mRNA abundance in skeletal muscle of Holstein dairy cows after calving compared with the prepartum stage, indicating increased proteolytic activity. However, information on the mobilization of body reserves in cows with high body condition versus cows with normal body condition is limited, particularly concerning the regulation of protein metabolism in the skeletal muscle of cows during late gestation and early lactation when comprehensive endocrine and metabolic changes occur.

To address these issues, we used an experimental model in dairy cows for high versus normal mobilization around calving by feeding different diets (energy levels) before dry-off based on preselection [as quantified by BCS and backfat thickness (BFT)] in the previous and the ongoing lactations (Schuh et al., 2019). We hypothesized that cows calving with high BCS are metabolically challenged during early lactation due to a more severe NEB and intense mobilization of body fat that may also affect the regulation of specific signaling components related to protein synthesis and protein degradation. Therefore, we evaluated the effects of BCS around calving on mRNA abundance of key factors of the mTOR pathway and UPS in the skeletal muscle of dairy cows.

\section{MATERIALS AND METHODS}

\section{Animals, Management, and Treatments}

The experiment was conducted at the Educational and Research Centre for Animal Husbandry, Hofgut Neumuehle, Muenchweiler a.d. Alsenz, Germany. The experimental procedures in this study were performed 
in accordance with the German Animal Welfare Act and were approved by the local authority for animal welfare affairs [Landesuntersuchungsamt RheinlandPfalz (G 14-20-071), Koblenz, Germany]. The basic setup of the trial, the performance results, and the data of classical variables [i.e., nonesterified fatty acids (NEFA), BHB, insulin, glucose, leptin, IGF-1, and oxidative and thyroid hormone status] assessed in blood serum have been described by Schuh et al. (2019). In brief, 38 multiparous German Holstein cows (average parity: $2.9 \pm 0.30$, mean \pm SEM) were allocated to either the normal body condition group (NBCS; $\mathrm{n}=$ 19) or the high body condition group (HBCS; $\mathrm{n}=$ 19) $15 \mathrm{wk}$ before their anticipated calving date. These 2 groups were fed differently (for the diets, see Table 1) as detailed below from wk 15 to 7 before the anticipated calving date to reach different targets for BCS and BFT at dry-off (NBCS: $<3.5$ BCS and $<1.2-\mathrm{cm}$ BFT; HBCS: $>3.75 \mathrm{BCS}$ and $>1.4-\mathrm{cm} \mathrm{BFT)}$. The 2 groups were initially preselected from the entire herd (150 heads) by using BCS and BFT records from the year preceding the trial to find cows divergent in both variables in order to have 2 groups with equal numbers. The preselected cows were also stratified for comparable milk yields (NBCS: 10,361 \pm SD $302 \mathrm{~kg}$; HBCS: 10,315 $\pm 437 \mathrm{~kg}$ ). From wk 15 to 7 before the anticipated calving date, NBCS cows were fed a low-energy ration $(6.8$ MJ of $\mathrm{NE}_{\mathrm{L}} / \mathrm{kg}$ of DM), whereas HBCS cows were fed a high-energy ration $\left(7.2 \mathrm{MJ}\right.$ of $\mathrm{NE}_{\mathrm{L}} / \mathrm{kg}$ of $\left.\mathrm{DM}\right)$. During the dry period and subsequent lactation, both groups received an identical diet. All diets were fed as a TMR consisting of $63 \%$ roughage and $37 \%$ concentrate in the high-energy diet or $74 \%$ roughage and $26 \%$ concentrate in the low-energy diet. The diets were balanced to meet or exceed the nutritional requirements of Holstein cows according to the recommendations of the Society of Nutrition Physiology in Germany (GfE, 2001). One person monitored both BCS and BFT every 2 wk during the entire period of the trial (15 wk antepartum to $12 \mathrm{wk}$ postpartum). The BCS was estimated on a 5 -point scale with 0.25 increments $(1=$ emaciated, 5 = extremely fat; Edmonson et al., 1989), whereas BFT was assessed in the sacral region using ultrasonography (Agroscan L, ALR 500, 5-MHz linear-array transducer, Echo Control Medical, Angoulême, France). Net energy balance was calculated from wk 3 antepartum until wk 12 postpartum as previously described (Schuh et al., 2019).

\section{Sampling and Laboratory Analyses}

Individual daily feed intake was recorded from wk 3 antepartum until wk 12 postpartum as previously described (Schuh et al., 2019). Total mixed rations and the concentrate feed were sampled every $2 \mathrm{wk}$ and stored at $-20^{\circ} \mathrm{C}$ until analysis. Dry matter of the diets was determined by drying at $60^{\circ} \mathrm{C}$ for $24 \mathrm{~h}$ and then at $105^{\circ} \mathrm{C}$ for $3 \mathrm{~h}$. Analysis of the nutrient composition of the feed samples was carried out according to the methods of the Association of German Agricultural Analytic and Research Institutes (Naumann and Bassler, 2004). Samples were analyzed for CP, utilizable CP, crude ash, crude fat, crude fiber, NDF, ADF, and NFC. The minerals $(\mathrm{Ca}, \mathrm{P}, \mathrm{Mn}, \mathrm{Na}$, and $\mathrm{K}$ ) were analyzed using $\mathrm{X}$-ray fluorescence analysis. The energy content (ME and $\mathrm{NE}_{\mathrm{L}}$ ) of the diet was calculated according to the German Society of Nutrition Physiology (GfE, 2009).

Blood samples were collected from the vena caudalis mediana before the morning feeding on $\mathrm{d}-49,3,21$, and 84 relative to calving. After clotting and subsequent centrifugation $(10 \mathrm{~min}, 2,000 \times g)$, the serum was obtained and stored at $-20^{\circ} \mathrm{C}$ until analysis. The blood samples collected for metabolomics were stored at $-80^{\circ} \mathrm{C}$ until analysis. Biopsies from the semitendinosus were collected on the same days as blood sampling. The animals were sedated by intravenous injection of xylazine $(20 \mathrm{mg} / \mathrm{mL}, 0.1 \mathrm{~mL} / 100 \mathrm{~kg}$ of BW; CP-Pharma Handels GmbH, Burgdorf, Germany) and fixed in a

Table 1. Ingredient composition (\% of DM) and chemical composition ( $\mathrm{g} / \mathrm{kg}$ of DM, unless otherwise noted) of rations during the observation period for normal-conditioned (NBCS) and high-conditioned (HBCS) cows $^{1}$

\begin{tabular}{lcccc}
\hline & \multicolumn{2}{c}{ Late lactation } & & \\
\cline { 2 - 3 } Item & HBCS & NBCS & $\begin{array}{c}\text { Dry } \\
\text { period }\end{array}$ & $\begin{array}{c}\text { Early } \\
\text { lactation }\end{array}$ \\
\cline { 2 - 3 } Ingredient & & & & \\
Grass silage & 22.4 & 32.0 & 32.0 & 22.4 \\
Corn silage & 20.7 & 32.0 & 32.0 & 20.7 \\
Pressed beet pulp silage & 12.5 & - & - & 12.5 \\
Hay & 5.5 & 5.4 & 5.4 & 5.5 \\
Straw & 2.3 & 4.1 & 4.1 & 2.3 \\
Vitamin and mineral mix & 0.4 & 0.7 & 0.7 & 0.4 \\
Concentrate & 36.2 & 25.8 & 25.8 & 36.2 \\
Chemical composition & & & & \\
ME, MJ/kg of DM & 10.8 & 10.6 & 10.6 & 10.8 \\
NE, MJ/kg of DM & 7.2 & 6.8 & 6.8 & 7.2 \\
CP & 170 & 157 & 157 & 170 \\
Utilizable CP & 156 & 149 & 149 & 156 \\
NDF & 359 & 382 & 382 & 359 \\
ADF & 204 & 223 & 223 & 204 \\
NFC & 402 & 360 & 360 & 402 \\
Ruminal N balance, g/d & 3.4 & 2.3 & 2.3 & 3.4 \\
\hline
\end{tabular}

${ }^{1}$ Late lactation $=15$ to $7 \mathrm{wk}$ antepartum; dry period $=\mathrm{wk} 7$ antepartum to parturition; early lactation $=1$ to $14 \mathrm{wk}$ in milk. Dry period and early lactation values are for both HBCS and NBCS cows.

${ }^{2}$ Contained (DM basis) 9.0\% Ca, 9.0\% P, 9.0\% Na, 10\% Mg, 10,000 $\mathrm{mg} / \mathrm{kg} \mathrm{Zn,} \mathrm{6,000} \mathrm{mg/kg} \mathrm{Mn,} \mathrm{1,500} \mathrm{mg/kg} \mathrm{Cu,} 60 \mathrm{mg} / \mathrm{kg}$ Co, $200 \mathrm{mg} /$ $\mathrm{kg}$ I, $53 \mathrm{mg} / \mathrm{kg}$ Se, $1,000 \mathrm{kIU} / \mathrm{kg}$ vitamin A, $150 \mathrm{kIU} / \mathrm{kg}$ vitamin $\mathrm{D}_{3}$, and $6 \mathrm{kIU} / \mathrm{kg}$ vitamin E.

${ }^{3}$ Concentrate portion consisted of barley ( $25 \%$ of DM), corn grain (31\% of DM), soybean meal ( $18 \%$ of DM), and canola meal $(26 \%$ of $\mathrm{DM})$. 
headlock. The biopsy area was cleaned, shaved, and disinfected with $70 \%$ isopropyl alcohol. Muscle samples were obtained under local anesthesia with procaine hydrochloride $(20 \mathrm{mg} / \mathrm{mL}, 8 \mathrm{~mL} /$ biopsy; Richter Pharma AG, Wels, Austria) using a $12-\mathrm{G} \times 20$-cm core tissue biopsy needle with a Bard Magnum (Bard Inc., Tempe, AZ). After tissue extraction, oxytetracycline hydrochloride was applied on the skin $(25 \mathrm{mg} / \mathrm{mL}$, Engemycin, MSD Animal Health Innovation GmbH, Schwabenheim an der Selz, Germany), and a ketoprofen injection (100 $\mathrm{mg} / \mathrm{mL}, 3 \mathrm{~mL} / 100 \mathrm{~kg}$ of BW; Streuli Pharma AG, Uznach, Germany) was given to prevent infection and pain. Tissue samples were immediately snap-frozen in liquid nitrogen and stored at $-80^{\circ} \mathrm{C}$ until analysis.

Serum 3-methylhistidine (3-MH) was analyzed via HPLC in an RF-10A XL fluorescence detector (Shimadzu, Kyoto, Japan) based on o-phtaldialdehyde/3mercaptopropionic acid derivatization as previously described (Fürst et al., 1990).

The AA profiles in serum and skeletal muscle as well as serum creatinine were determined using liquid chromatography-electrospray ionization-tandem MS profiling through targeted metabolomics using a AbsoluteIDQ p180 kit (Biocrates Life Sciences AG, Innsbruck, Austria). This kit was validated according to European Medicines Agency guidelines (EMA, 2011), which implies a proof of reproducibility within a given error range. All analyses were performed in the Genome Analysis Center, Helmholtz Zentrum München, German Research Center for Environmental Health (Neuherberg, Germany). In the case of serum, $10 \mu \mathrm{L}$ of the thawed sample was applied directly to the assay. In the case of muscle, frozen samples were homogenized and extracted using homogenization tubes with ceramic beads $(1.4 \mathrm{~mm})$ and a Precellys 24 homogenizer with an integrated cooling unit (PEQLab Biotechnology GmbH, Erlangen, Germany). Three microliters of dry icecooled mixture of ethanol/phosphate buffer $(85 \% / 15 \%$ $\mathrm{vol} / \mathrm{vol}$ ) was added to each milligram of frozen muscle tissue. After centrifugation, $10 \mu \mathrm{L}$ of the homogenate supernatant was applied to the well plate of the p180 kit. The assay procedures of the AbsoluteIDQ p180 kit, details of the tissue preparation, and the metabolite nomenclature have been described in detail elsewhere (Zukunft et al., 2013, 2018). Samples were handled by a Hamilton Microlab STAR robot (Hamilton Bonaduz AG, Bonaduz, Switzerland) and an Ultravap nitrogen evaporator (Porvair Sciences, Leatherhead, UK) in addition to standard laboratory equipment. Mass spectrometric analyses were done on an API 4000 triple quadrupole system (Sciex Deutschland GmbH, Darmstadt, Germany) equipped with a 1200 Series HPLC (Agilent Technologies Deutschland GmbH, Böblin- gen, Germany) and an HTC PAL autosampler (CTC Analytics, Zwingen, Switzerland) controlled by Analyst 1.6.1 software (AB SCIEX Deutschland GmbH, Darmstadt, Germany). Data evaluation for quantification of metabolite concentrations and quality assessment were performed with the MetIDQ software package, which is an integral part of the AbsoluteIDQ kit. Internal standards were used as a reference for the calculation of metabolite concentrations. (The concentrations of the serum samples are given in $\mu \mathrm{mol} / \mathrm{L}$, and the concentrations of the tissue samples are given in $\mathrm{pmol} / \mathrm{mg}$ of tissue.)

Total RNA was extracted using Qiagen (Hilden, Germany) reagent from the muscle homogenates according to the manufacturer's protocol. The extracted RNA was purified using an RNeasy Mini kit (Qiagen) including the on-column DNase I treatment to remove residual genomic DNA from the RNA samples. The quantity and purity of RNA were evaluated by measuring the absorbance at 260 and $280 \mathrm{~nm}$ using the Nanodrop 1000 spectrophotometer (PEQLab Biotechnology). The RNA integrity was assessed using ethidium bromidedenaturing RNA electrophoresis and rechecked in randomly selected samples using an Agilent 2100 Bioanalyzer (Agilent Technologies, Waldbronn, Germany) with an RNA 6000 Nano kit system according to the manufacturer's protocol to determine RNA integrity number $(7.63 \pm 0.17 \mathrm{SD})$. Only samples with a $28 \mathrm{~s} / 18 \mathrm{~s}$ ratio $\geq 2.0$ and RNA integrity number $\geq 7.0$ were used for downstream applications. Reverse transcription was conducted with $250 \mathrm{ng}$ of total RNA per $20-\mu \mathrm{L}$ reaction using RevertAid reverse transcriptase $(200 \mathrm{U} / \mu \mathrm{L}$; Thermo Fisher Scientific, Dreireich, Germany), 20 U of RiboLock ribonuclease inhibitor (Fermentas, St. LeonRot, Germany), and $500 \mu M$ each deoxynucleotide triphosphate with 200 pmol of random hexamer primers (Sigma-Aldrich, Nümbrecht, Germany) for $10 \mathrm{~min}$ at $27^{\circ} \mathrm{C}, 60 \mathrm{~min}$ at $42^{\circ} \mathrm{C}$, and $1 \mathrm{~min}$ at $99^{\circ} \mathrm{C}$. Each run included a no-reverse-transcriptase control and a notemplate control. Reverse transcription was performed in duplicate for each sample. The analyses by quantitative real-time PCR (qPCR) were performed using an Mx3000P PCR cycler (Stratagene, Amsterdam, the Netherlands) following the original Minimum Information for Publication of qPCR Experiments guidelines (Bustin et al., 2009). The qPCR conditions and the characteristics of the primers are presented in Table 2 . The reaction was performed in triplicate in a total volume of $10 \mu \mathrm{L}$ comprising $2 \mu \mathrm{L}$ of cDNA (diluted 1:4) as a template, $1 \mu \mathrm{L}$ of the assay-specific primer mix, 5 $\mu \mathrm{L}$ of SYBR Green JumpStart Taq Readymix (SigmaAldrich Chemie GmbH, Steinheim, Germany), and 2 $\mu \mathrm{L}$ of water. A no-template control for quantitative 
Table 2. Characteristics of primers and real-time PCR conditions

\begin{tabular}{|c|c|c|c|c|c|}
\hline Gene $^{1}$ & Sequence $\left(5^{\prime}-3^{\prime}\right)$ & NCBI accession no. & $\mathrm{bp}$ & $\begin{array}{c}\text { Annealing, }{ }^{2} \\
\mathrm{~s} /{ }^{\circ} \mathrm{C}\end{array}$ & $\begin{array}{c}\text { Mean } \\
\text { efficiency }\end{array}$ \\
\hline \multicolumn{6}{|l|}{$m T O R$} \\
\hline Forward & CGAAACCCTGGATGTCCCAA & XM_002694043.2 & 94 & $30 / 61$ & 96.1 \\
\hline \multicolumn{6}{|c|}{ (1) } \\
\hline Forward & CCCTGGAGGTACCAGGATCA & NM_001077893.2 & 125 & $60 / 62$ & 103.3 \\
\hline Reverse & CATCGCCTGTAGGGCTAGTG & & & & \\
\hline \multicolumn{6}{|c|}{. } \\
\hline \multicolumn{6}{|c|}{ 70 } \\
\hline Forward & GGGGAACCGGCATTGATGT & NM_001102477.1 & 118 & $60 / 59$ & 92.2 \\
\hline Reverse & AGGGCACTTCGGACAATACG & & & & \\
\hline \multicolumn{6}{|l|}{ UBE2G1 } \\
\hline Forward & TATGCTGGCAGACCCCAATG & NM_001082458.1 & 109 & $60 / 59$ & 103.3 \\
\hline Reverse & TCTTACACAGCGGGCAACTT & & & & \\
\hline \multicolumn{6}{|l|}{ Atrogin-1 } \\
\hline Reverse & TCTTCTTGGCTGCAACGTCA & & & & \\
\hline \multicolumn{6}{|c|}{ 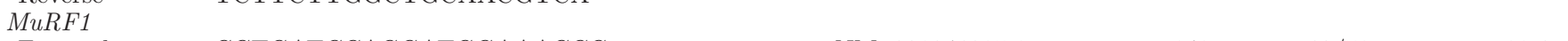 } \\
\hline Forward & CCTGATCCAGGATGGAAACCC & NM_001046295.1 & 149 & $60 / 59$ & 89.6 \\
\hline Reverse & CAGCCTGCTGGAAGATGTCGT & & & & \\
\hline \multicolumn{6}{|c|}{ 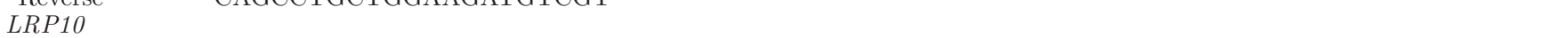 } \\
\hline Forward & CCAGAGGATGAGGACGATGT & BC149232 & 125 & $45 / 59$ & 98.4 \\
\hline Reverse & ATAGGGTTGCTGTCCCTGTG & & & & \\
\hline \multicolumn{6}{|l|}{ POL2RA } \\
\hline Forward & GAAGGGGGAGAGACAAACTG & X63564 & 86 & $60 / 60$ & 100.4 \\
\hline Reverse & GGGAGGAAGAAGAAAAAGGG & & & & \\
\hline \multicolumn{6}{|c|}{ (6) } \\
\hline Forward & GCCCTCAGCTTCACTCTCAGA & NM_203361 & 100 & $45 / 59$ & 95.5 \\
\hline Reverse & GAGGCGTTCCCGATCCTT & & & & \\
\hline \multicolumn{6}{|l|}{ EIF3K } \\
\hline
\end{tabular}

${ }^{1} m T O R=$ mammalian target of rapamycin; $4 E B P 1=$ eukaryotic translation initiation factor $4 \mathrm{E}$ binding protein $1 ; S 6 K 1=$ ribosomal protein S6 kinase, polypeptide 1; UBA1 = ubiquitin-like modifier activating enzyme 1; UBE2G1 = ubiquitin-conjugating enzyme E2G 1; UBE2G2 = ubiquitin-conjugating enzyme E2G 2;MuRF1 = muscle ring-finger protein-1; LRP10 = lipoprotein receptor-related protein 10; $P O L 2 R A=$ RNA polymerase II; EMD = emerin; EIF3K = eukaryotic translation initiation factor 3 subunit $\mathrm{K}$.

${ }^{2}$ Initial denaturation for $10 \mathrm{~min}$ at $90^{\circ} \mathrm{C}$; denaturation for $30 \mathrm{~s}$ at $95^{\circ} \mathrm{C}$; extension for $30 \mathrm{~s}$ at $72^{\circ} \mathrm{C}$, except for $4 E B P 1, U B A 1, U B E 2 G 1, U B E 2 G 2$, MuRF1 $\left(60 \mathrm{~s}\right.$ at $\left.72^{\circ} \mathrm{C}\right)$, and $\operatorname{LRP} 10\left(20 \mathrm{~s}\right.$ at $\left.72^{\circ} \mathrm{C}\right)$.

PCR as well as a no-template control and no-reversetranscriptase control of cDNA were included in each run. For each PCR reaction, a standard curve using a serial dilution of cDNA was generated to calculate efficiency-corrected relative quantities of the targets (run-specific target amplification efficiency).

To determine the most stably expressed genes across treatments for subsequent data normalization, a set of 5 genes (Saremi et al., 2012) was tested, and their stability was evaluated using qBASE+ version 2.0 (Biogazelle, Ghent, Belgium). Three reference genes, including low-density lipoprotein receptor-related protein 10 (LRP10), RNA polymerase II (POLR2A), and emerin $(E M D)$, were determined to be the most stable reference genes (Table 2). All subsequent calculations and data quality controls were performed using qBASE+ software (Hellemans et al., 2007). The output data from the software were calibrated normalized relative quantities.

\section{Statistical Analyses}

A repeated-measures model was fitted to the data using PROC MIXED of SAS (version 9.4; SAS Institute Inc., Cary, NC). Before analysis, all data were tested for normality of distribution by evaluating the ShapiroWilk statistic using PROC UNIVARIATE of SAS, and, where appropriate, they were transformed using a $\log _{10}$ transformation. The model consisted of treatment, time (day relative to calving), and interaction of treatment and time as fixed effects and cow as the random effect. An autoregressive (order 1) covariance structure was 
chosen based on the Akaike and Bayesian information criteria. The final results of the mRNA abundance were calculated using qBASE+ (i.e., the calibrated normalized relative quantities values were used for statistical analysis of the mRNA data). When differences were detected in the treatment or interaction, means separation was conducted using a Tukey's adjustment for the probability. The threshold of significance was set at $P$ $\leq 0.05$; trends were declared at $0.05<P \leq 0.10$.

\section{RESULTS}

\section{Body Condition and Animal Performance}

A more detailed description of the variables characterizing body condition as well as animal performance was reported previously (Schuh et al., 2019). In brief, BCS, BFT, and BW (Supplemental Figure S1, https:// doi.org/10.3168/jds.2019-17130) were greater in HBCS cows than in NBCS cows at enrollment (15 wk antepartum). However, when both groups received the same diets during the dry period, they increased their body condition whereby the previously established differences $(\Delta=0.7$ BCS points and $1.1 \mathrm{~cm}$ of BFT) were largely maintained until the week before calving (Figure 1A, B). Body condition declined during lactation in both groups, but the losses were bigger in HBCS cows than in NBCS cows (Figure 1C, D). Dry matter intake (Figure 1E) was greater in NBCS cows than in HBCS cows until calving, when both groups reached the same nadir 1 wk postpartum. During the subsequent weeks, NBCS cows had a faster increase in feed intake; the difference between groups leveled off in wk 11 postpartum The calculated energy balance (Figure $1 \mathrm{~F}$ ) was greater in NBCS cows than in HBCS cows during the antepartum period and reached positive values about 2 wk earlier than in the HBCS cows.

\section{Concentrations of AA in Serum and Skeletal Muscle}

The concentrations of serum AA during the transition from late pregnancy to early lactation are presented in Figure 2. Serum Arg, Asn, Asp, Glu, Ser, and Thr were not different between the groups. Circulating concentrations of total AA and most AA except Gly, Gln, Met, and Phe increased with time of lactation in both groups. The serum concentrations of Ala $(P<0.01$, d +21 and +84$)$ and $\operatorname{Orn}(P=0.01, \mathrm{~d}+84)$ were lower but those of Gly $(\mathrm{d}-49)$, His $(\mathrm{d}-49)$, Leu $(\mathrm{d}-49)$, Val $(\mathrm{d}-49)$, Lys $(\mathrm{d}-49)$, Ile $(\mathrm{d}+21)$, Met $(\mathrm{d}-49)$, and Orn $(\mathrm{d}-49)$ were greater $(P<0.05)$ in HBCS cows than in NBCS cows. The serum concentrations of Gln $(P=0.07, \mathrm{~d}-49)$ and Tyr $(P=0.09, \mathrm{~d}-49)$ tended to be greater in HBCS cows than in NBCS cows, whereas those of Cys, Phe, Pro, and Trp were similar between groups. The serum concentrations of total free AA were greater $(P<0.01)$ in HBCS cows than in NBCS cows on $\mathrm{d}-49$ and +21 . The serum concentrations of $3-\mathrm{MH}$, creatinine, and 3-MH:creatinine ratio were elevated on $\mathrm{d}+3(P<0.01)$ compared with other time points but did not differ between groups (Figure 3 ).

The concentrations of muscle AA are presented in Table 3. The concentrations of all AA except for Cys and His remained unchanged during the observation period and did not differ between groups. The muscle concentrations of Cys were greater $(P<0.05)$ in HBCS cows than in NBCS cows on $\mathrm{d}-49$ but tended $(P=$ 0.07 ) to be lower on $d+21$. For time-related differences, the muscle concentrations of His $(P=0.03)$ increased from late pregnancy to early lactation in both groups. The concentrations of total free AA in muscle were not affected by group or by time, and there was no group $\times$ time interaction.

\section{mRNA Abundance in the Skeletal Muscle}

As shown in Figure 4, the mRNA abundance of mTOR was greater $(P<0.05)$ and that of eukaryotic translation initiation factor $4 \mathrm{E}$ binding protein 1 ( $4 E B P 1)$ tended $(P=0.07)$ to be greater in HBCS cows than in NBCS cows on $d+21$, but there was no time or group $\times$ time interaction. The mRNA abundance of ribosomal protein S6 kinase 1 (S6K1) was not affected by group or by time, and there was no group $\times$ time interaction (Figure 4).

The mRNA abundance of ubiquitin-activating enzyme (UBA1), ubiquitin-conjugating enzyme 1 (UBE2G1), and atrogin-1 was not affected by group or time (Figure 5). However, a group $\times$ time interaction was observed for the mRNA abundance of $U B A 1(P=$ $0.001), U B E 2 G 1(P=0.04)$, and atrogin-1 $(P=0.03)$; it was greater on $d+21$ in HBCS cows than in NBCS cows (Figure 3). The abundance of ubiquitin-conjugating enzyme 2 (UBE2G2) mRNA was not affected by group or time, and a group $\times$ time interaction was not observed (Figure 5). The mRNA abundance of MuRF1 was greater $(P=0.05)$ in HBCS cows than in NBCS cows on $\mathrm{d}+3$, but there was no time or group $\times$ time interaction (Figure 5).

\section{DISCUSSION}

It has been well documented that high-yielding dairy cows may experience negative nutrient balance during the periparturient period (Drackley, 1999; Rukkwamsuk et al., 1999), leading to mobilization of body fat and muscle protein as feed intake alone cannot meet the nutrient requirements (Heuer et al., 1999; Kuhla 
(A)

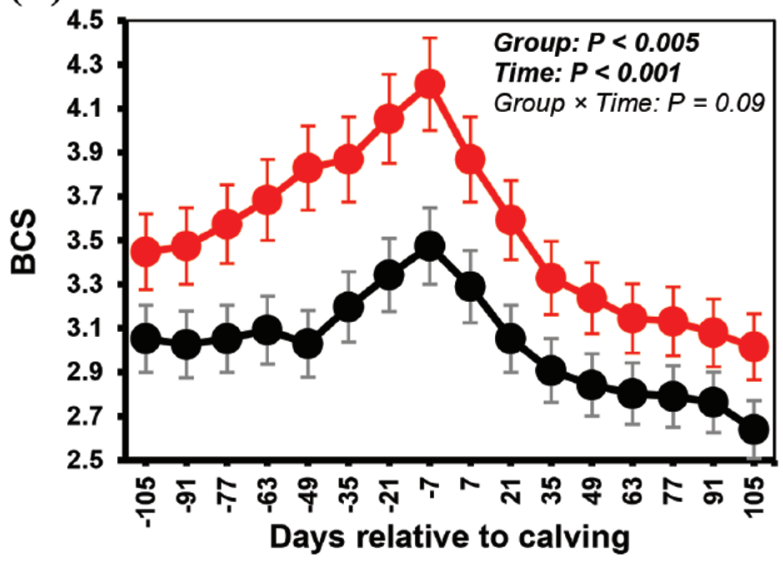

(C)

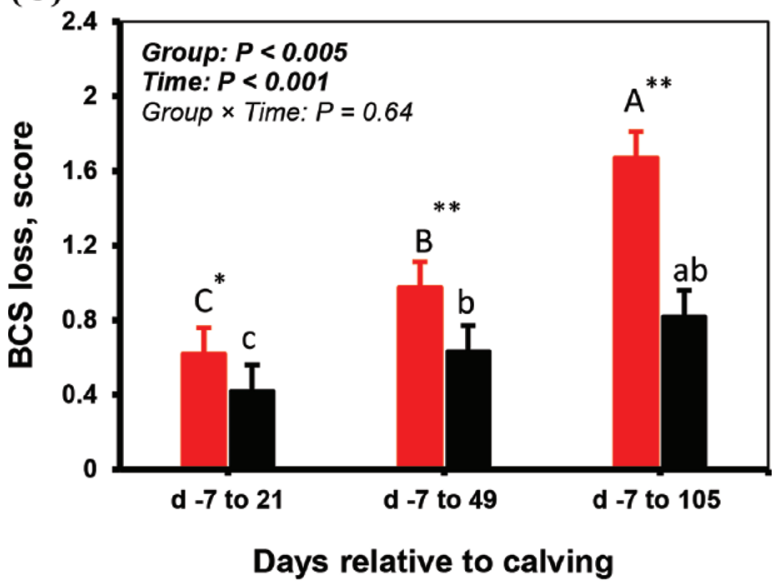

(E)

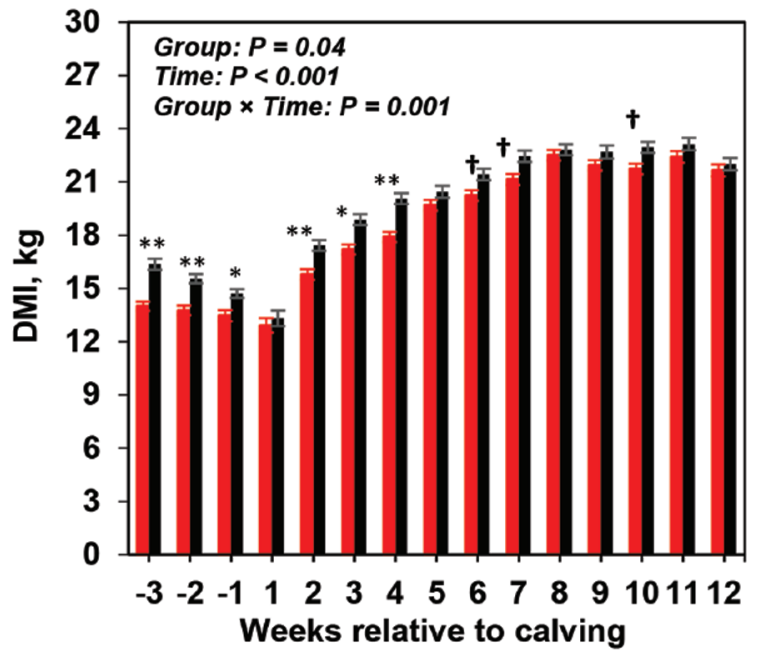

(B)

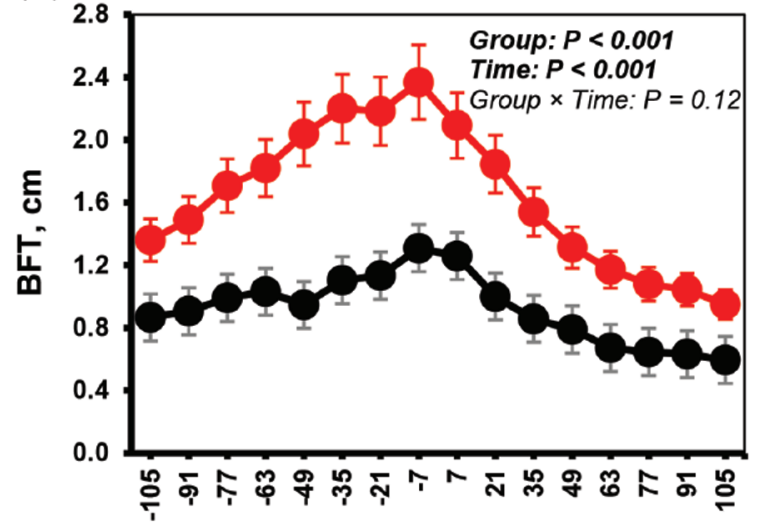

Days relative to calving

(D)

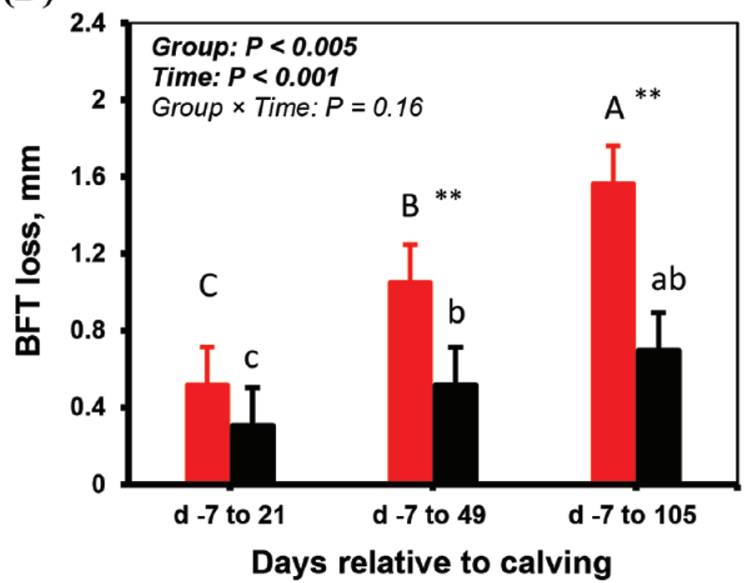

(F)

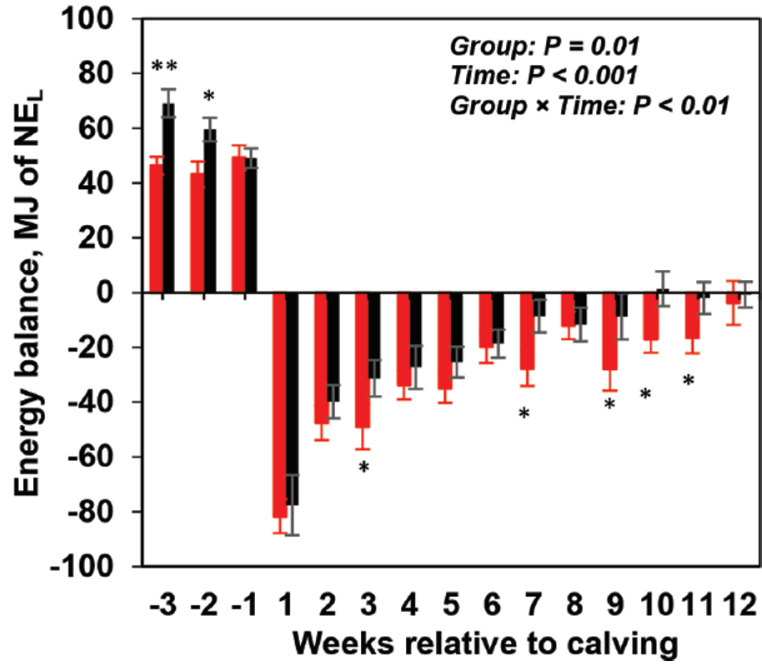

Figure 1. Changes in (A) BCS, (B) backfat thickness (BFT), (C) BCS loss, (D) BFT loss, (E) DMI, and (F) energy balance of normalconditioned (NBCS) and overconditioned (HBCS) cows during the experimental period $(\mathrm{n}=18 /$ treatment). Symbols indicate a difference $(* P$ $\left.<0.05 ;{ }^{*} P<0.01\right)$ or a trend $(\dagger P<0.1)$ between the groups at a given time. Data for BCS, BFT, BCS loss, BFT loss, DMI, and energy balance are from Schuh et al. (2019). Data are presented as means \pm SEM. Different uppercase letters (A-C) indicate differences between time points within HBCS cows, and different lowercase letters $(\mathrm{a}-\mathrm{c})$ indicate differences between time points within NBCS cows. Bold values indicate statistical significance $(P<0.05)$ 
(A)

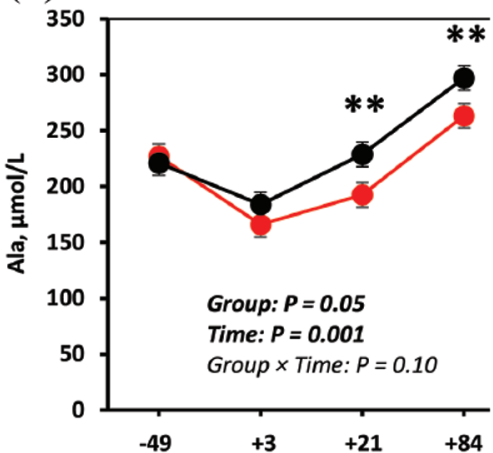

(D)

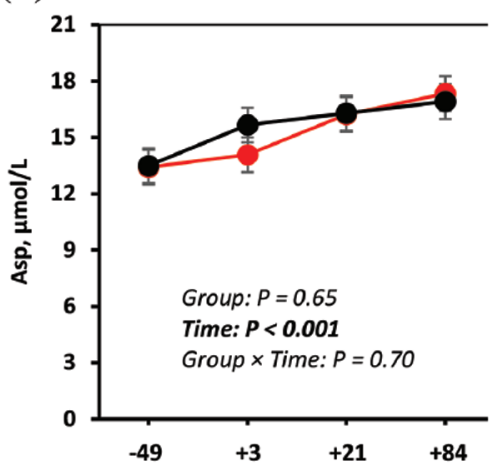

(G)

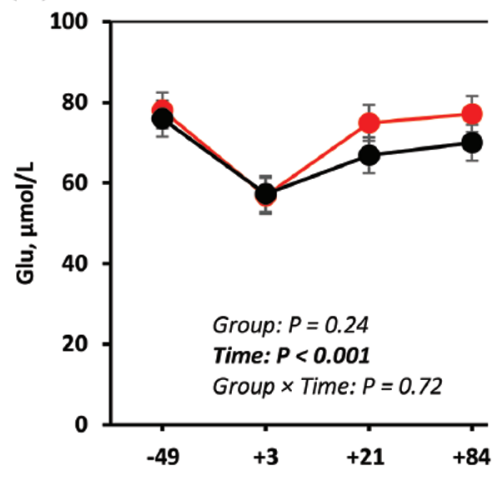

(J)

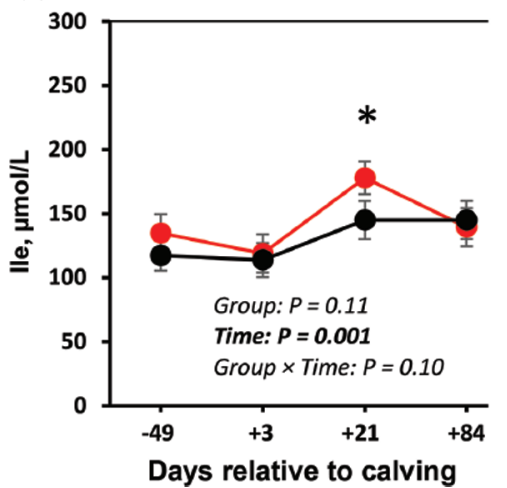

(B)

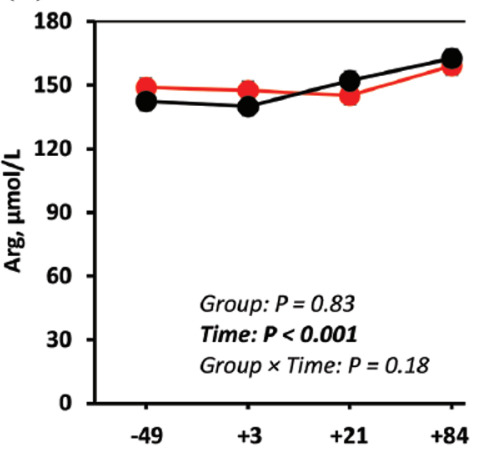

(E)

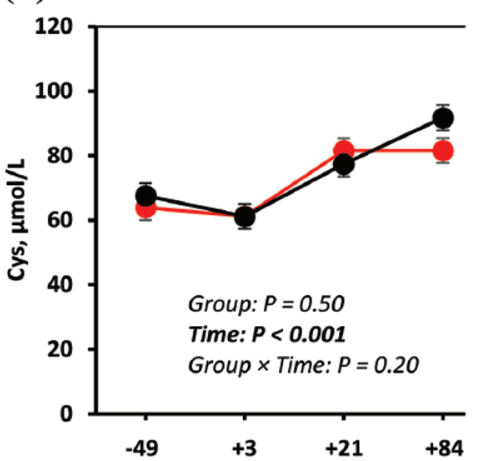

(H)

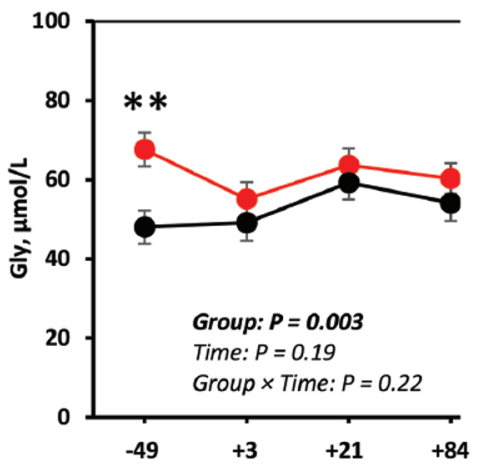

(K)

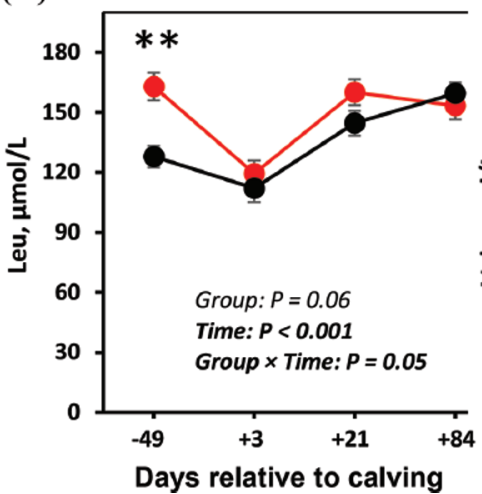

(C)

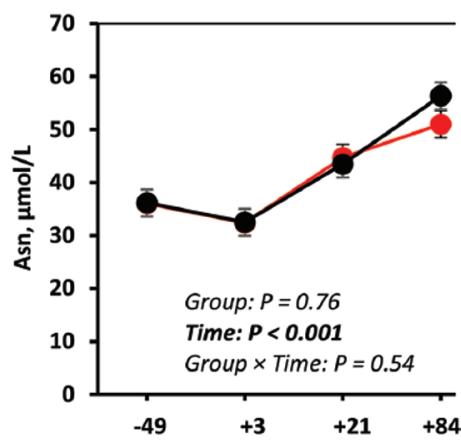

(F)

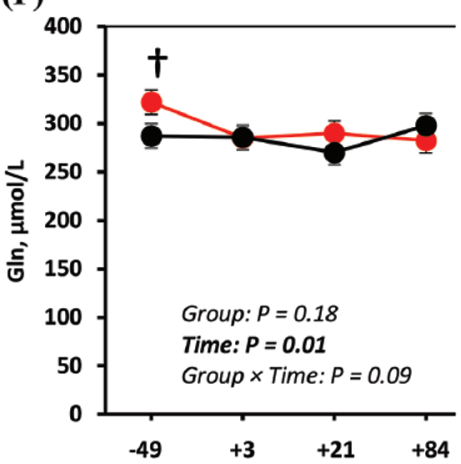

(I)

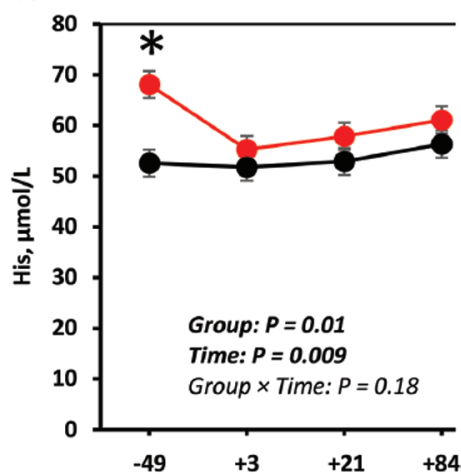

(L)

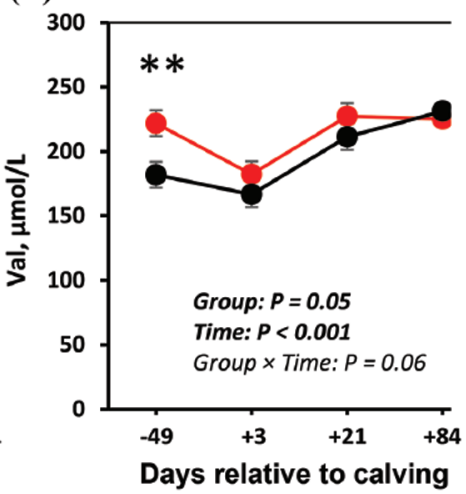

Figure 2. Serum amino acids concentrations $(\mu \mathrm{mol} / \mathrm{L})$ of normal-conditioned (NBCS) and overconditioned (HBCS) cows during the observation period $\left(\mathrm{n}=18 /\right.$ treatment). Symbols indicate a difference $\left({ }^{*} P<0.05 ;{ }^{*} P<0.01\right)$ or a trend $(\dagger P<0.1)$ between the groups at a given time. Data are presented as means \pm SEM. 
(M)

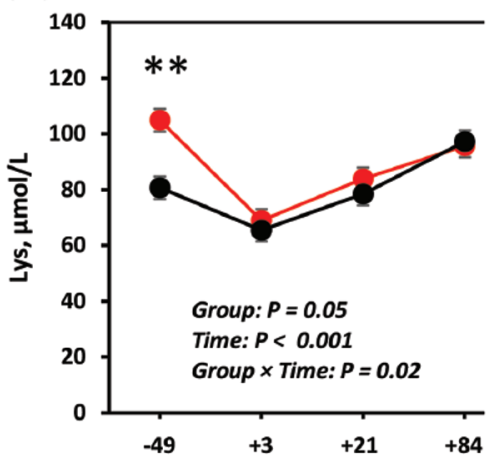

(P)

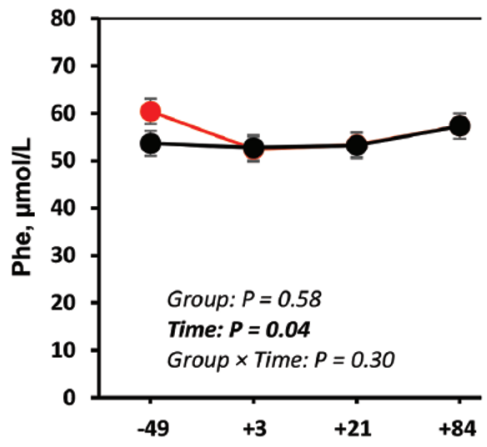

(S)

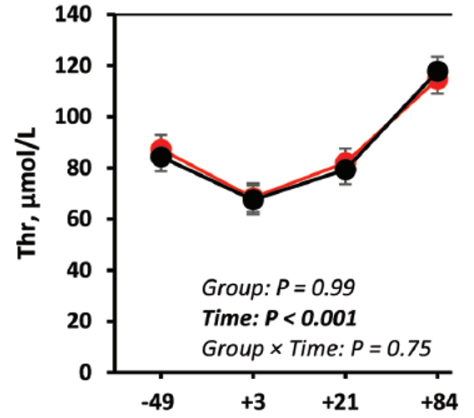

(Y)

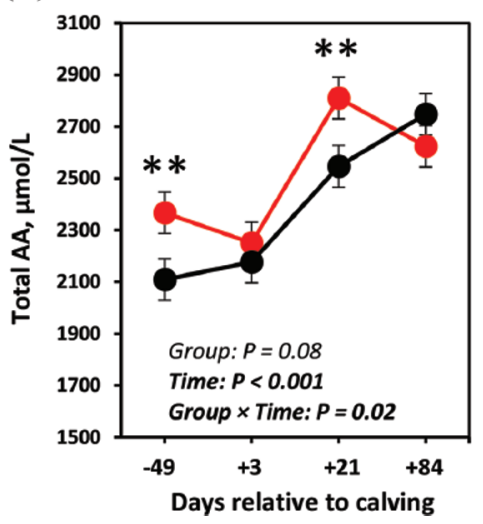

HBCS $\square$ NBCS

(N)

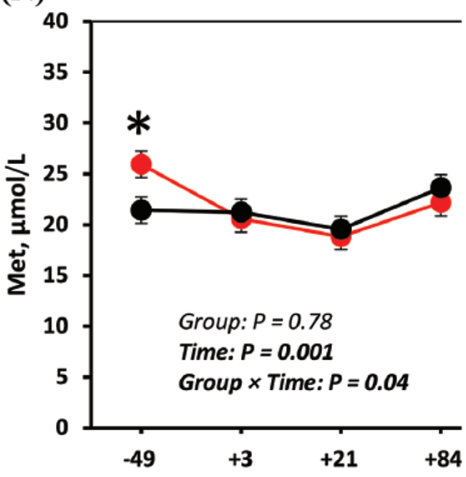

(Q)
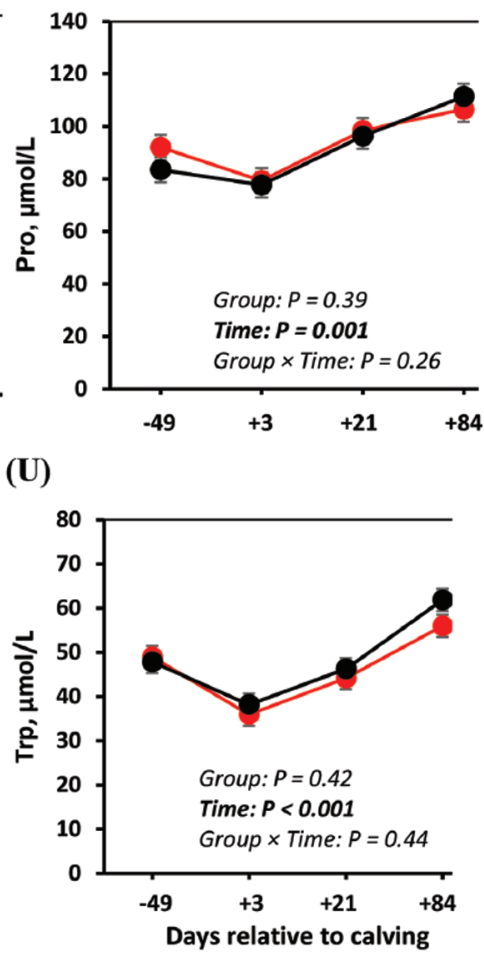

(R)

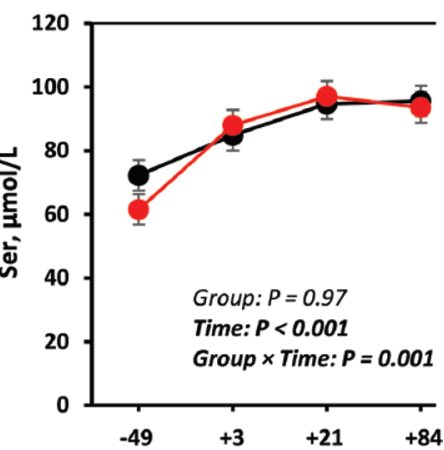

(W)
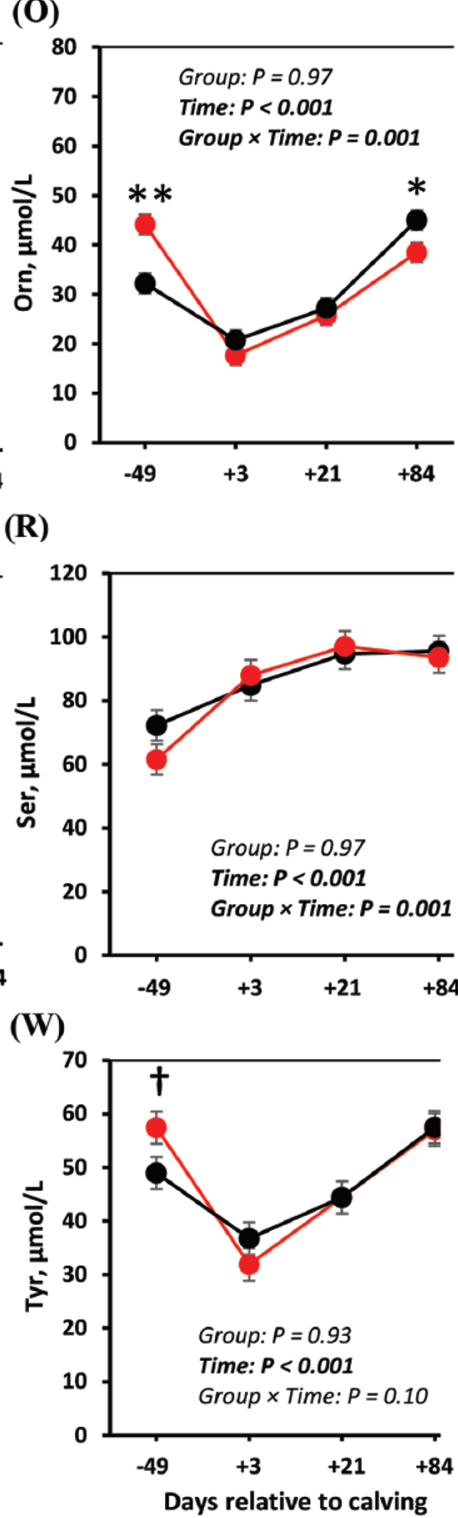

Figure 2 (Continued). Serum amino acids concentrations $(\mu \mathrm{mol} / \mathrm{L})$ of normal-conditioned (NBCS) and overconditioned (HBCS) cows during the observation period $(\mathrm{n}=18 /$ treatment $)$. Symbols indicate a difference $(* P<0.05 ; * * P<0.01)$ or a trend $(\dagger P<0.1)$ between the groups at a given time. Data are presented as means \pm SEM. 
(A)

$\square$ HBCS NBCS
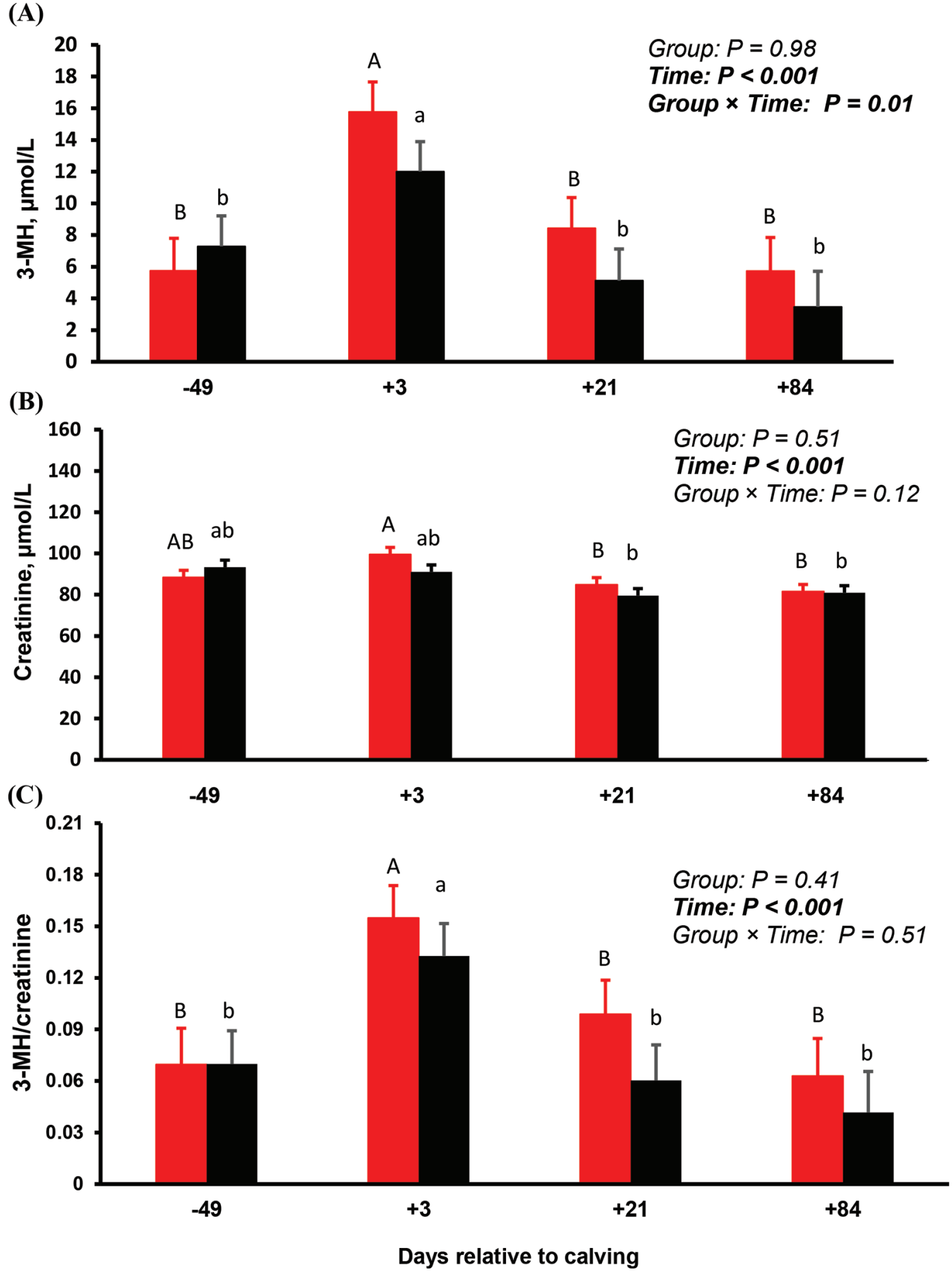

Figure 3. Serum concentrations of (A) 3-methylhistidine (3-MH), (B) creatinine, and (C) 3-MH:creatinine ratio of normal-conditioned (NBCS) and overconditioned (HBCS) cows during the observation period $(\mathrm{n}=18 /$ treatment). Results are presented as means \pm SEM. Different uppercase letters $(\mathrm{A}, \mathrm{B})$ indicate differences between time points within $\operatorname{HBCS}$ cows $(\mathrm{n}=18)$, and different lowercase letters $(\mathrm{a}$, b) indicate differences between time points within NBCS cows $(\mathrm{n}=18)$. Bold values indicate statistical significance $(P<0.05)$. 
et al., 2011; van der Drift et al., 2012). High-yielding cows experience some degree of oxidative stress in early lactation, and cows with higher BCS and greater BCS losses at parturition are more sensitive to oxidative stress compared with cows with low or medium BCS (Bernabucci et al., 2005). Previously, Schulz et al. (2014) described the pathophysiological serum alterations such as high values of NEFA, aspartate transaminase, and glutamate dehydrogenase in overconditioned cows developing subclinical ketosis in early lactation.
Mann et al. (2016) recently reported peripartal skeletal muscle accretion and proteolysis in cows with excess energy consumption compared with cows fed a highfiber, controlled-energy diet during the prepartum period. The dry period plane of energy did not lead to changes in BW or BCS (high-energy group $=3.1 \pm$ 0.2 ; control group $=3.1 \pm 0.3$; mean $\pm \mathrm{SE}$ ) as reported earlier (Mann et al., 2015). Thus, in the study by Mann et al. (2016), peripartal skeletal muscle accretion and proteolysis were investigated in mid-range-scoring cows,

Table 3. Skeletal muscle AA concentrations (pmol/mg of tissue) of normal-conditioned (NBCS) and overconditioned (HBCS) cows during the observation period

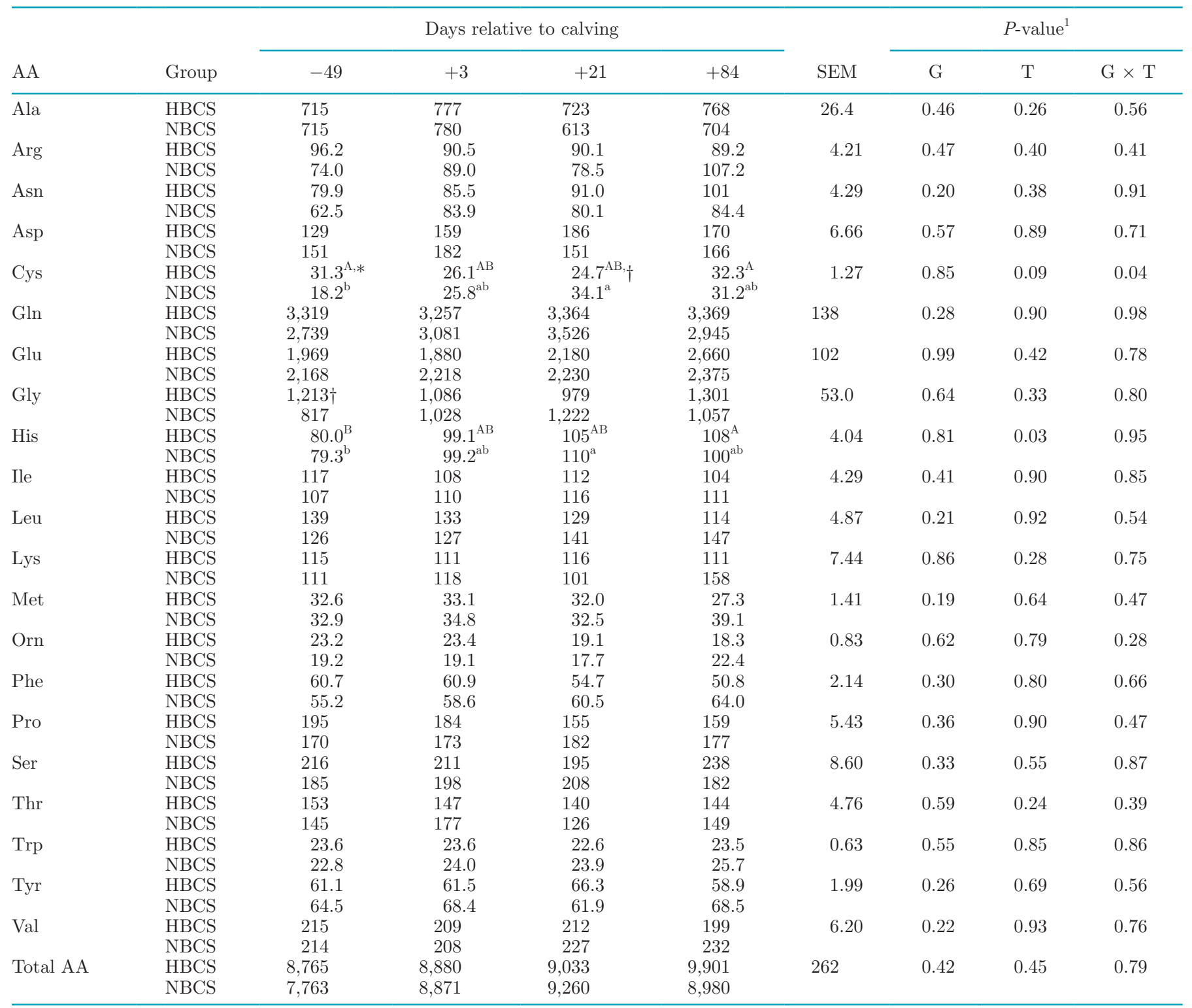

\footnotetext{
${ }^{\mathrm{A}, \mathrm{B}}$ Means within a row with different uppercase letters are different between time points within HBCS cows.

${ }^{\mathrm{a}, \mathrm{b}}$ Means within a row with different lowercase letters are different between time points within NBCS cows.

${ }^{1} \mathrm{G}=$ group effect; $\mathrm{T}=$ time effect; $\mathrm{G} \times \mathrm{T}=$ group $\times$ time interaction.

*Differences between the groups $(P \leq 0.05)$ at a given time point. $\nmid$ Trend for differences between the groups $(P<0.1)$ at a given time point.
} 
and indeed no comparison has been made concerning mobilization of body reserves in overconditioned cows compared with normal-conditioned cows.

During the transition period, rapid fetal growth, lactogenesis, synthesis of milk protein, and gluconeogenesis require large amounts of certain AA that are withdrawn from circulation and may lead to an imbalanced AA pattern in the blood (Kuhla et al., 2011). Plasma AA status is a net result of all fluxes involved in

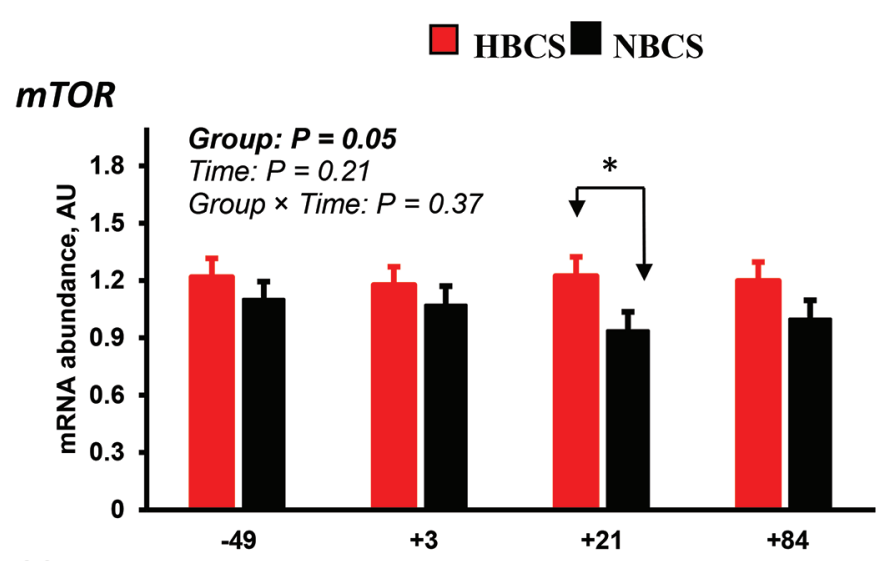

S6K1
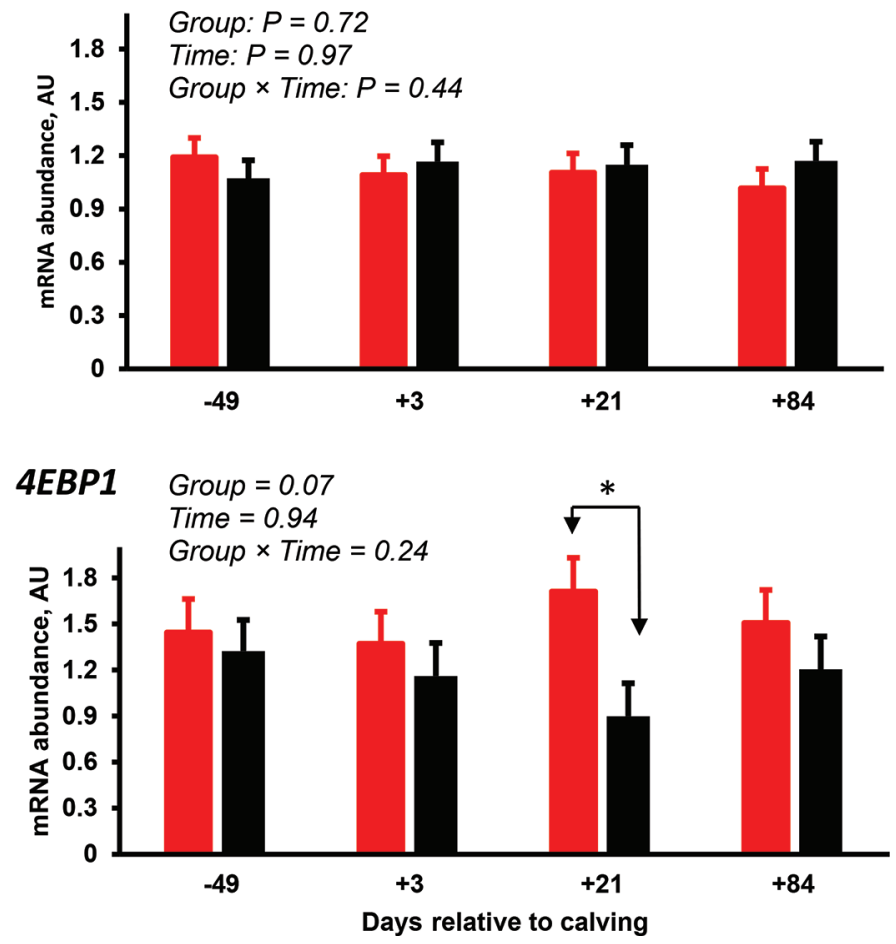

Figure 4. The mRNA abundance of genes related to the mammalian target of rapamycin (mTOR) pathway in the skeletal muscle of normal-conditioned (NBCS) and overconditioned (HBCS) cows $(\mathrm{n}=$ $18 /$ treatment). Symbols indicate a difference $(* P<0.05)$ between the groups at a given time. $S 6 K 1=$ ribosomal protein $S 6$ kinase, polypeptide $1 ; 4 E B P 1=$ eukaryotic translation initiation factor $4 \mathrm{E}$ binding protein. Data are presented as means \pm SEM. Bold values indicate statistical significance $(P<0.05)$. $\square$ HBCS $\square$ NBCS
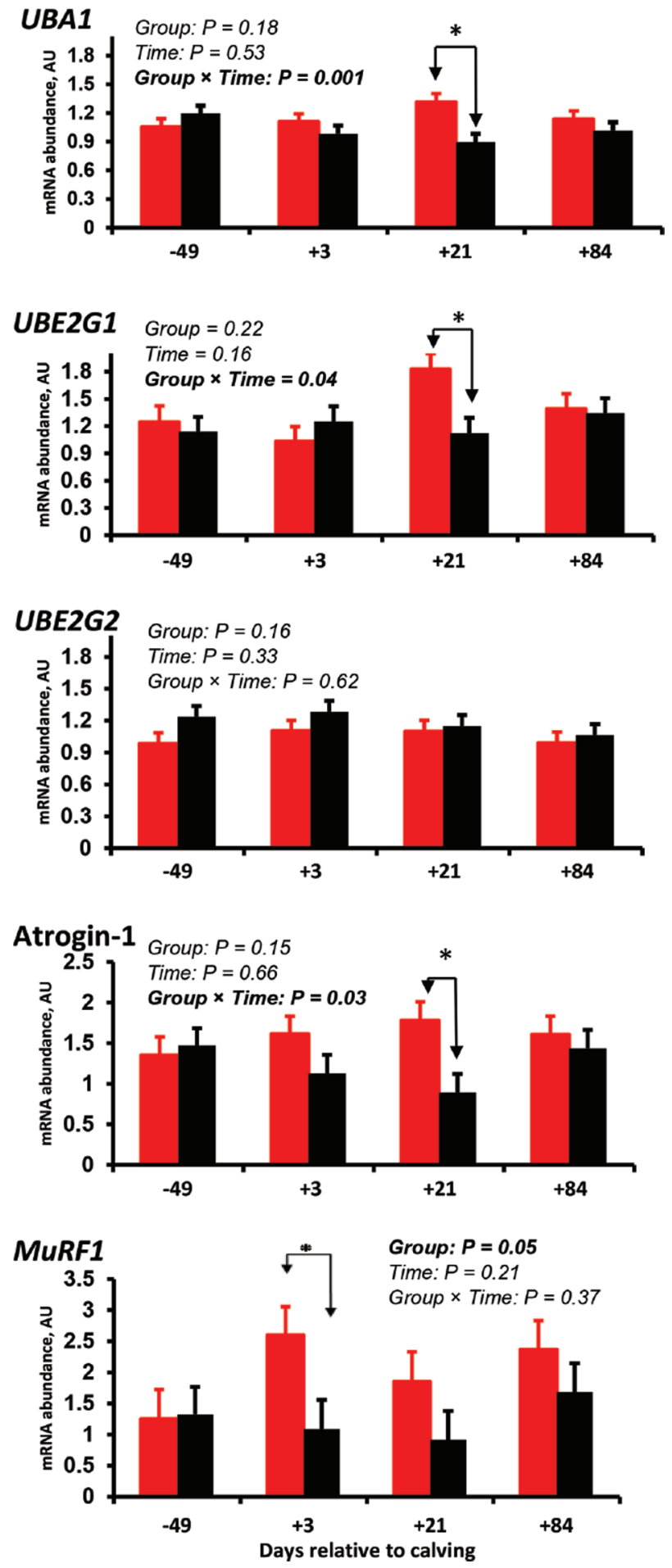

Figure 5. The mRNA abundance of genes related to the ubiquitin-proteasome system in the skeletal muscle of normal-conditioned (NBCS) and overconditioned (HBCS) cows ( $\mathrm{n}=18 /$ treatment). Symbols indicate a difference $(* P<0.05)$ between the groups at a given time. $U B A 1=$ ubiquitin-like modifier activating enzyme 1 ; $U B E 2 G 1$ and $U B E 2 G 2=$ ubiquitin-conjugating enzymes; $M u R F 1=$ muscle ring-finger protein-1. Data are presented as means \pm SEM. Bold values indicate statistical significance $(P<0.05)$. 
AA absorption from the digestive tract, muscle protein turnover, liver uptake of glucogenic AA, milk protein synthesis, and metabolic rate (Maeda et al., 2012; Samman et al., 2014). Regarding the changes in serum AA concentrations in the current study, overconditioned cows had higher Gly, His, Val, Leu, Lys, Met, Orn, and Tyr concentrations in the serum than NBCS cows on $\mathrm{d}-49$. The reason for the changes observed in the serum AA concentrations of HBCS and NBCS cows on $\mathrm{d}-49$ is not clear but might be, at least in part, due to the different diets used in these cows from wk 15 to 7 before calving, as the observed differences largely disappeared on $\mathrm{d}+3$ (i.e., after receiving the identical diets). In the current study, the concentrations of Ala, Asn, Glu, Cys, Pro, Val, Leu, Orn, Lys, Thr, Trp, and Tyr for both groups decreased from $\mathrm{d}-49$ to $\mathrm{d}$ +3 , with nadir concentrations on $\mathrm{d}+3$ and a gradual increase thereafter. These reductions in the serum concentrations might be due to the decreased DMI around calving (Figure 1E) or an increase in the uptake of AA into tissues, in particular the mammary gland (Verbeke et al., 1972). Skeletal muscle, the main labile source of AA in the body, plays important roles in maintaining AA homeostasis. Thus, a shift toward mobilization of body reserves, including muscle protein at the onset of lactation as well as increased DMI with time of lactation, may be responsible for the return of most serum AA concentrations to their prepartum values within a few weeks after calving (Meijer et al., 1995).

Moreover, the lower serum concentrations of Ala in HBCS cows during the postpartum period may be related to a greater demand for gluconeogenic AA for the liver (Chibisa et al., 2008) that is likely coupled with a reduced supply of ruminal propionate to the liver as a result of decreased DMI after calving (Schuh et al., 2019). In support of this, the quantitative data on liver metabolism of AA have shown an increased contribution of Ala to the immediate postpartum increase in the liver release of glucose, likely through its role in the interorgan transfer of nitrogen from catabolized AA (Larsen and Kristensen, 2013). In the current study, the concentrations of most AA (except for Cys and His) in muscle remained fairly constant throughout the observation period despite a decline in serum levels. The reason for these observations is not clear, but muscle appears to have increased transport activity to offset the decline in serum concentrations and thus maintain intracellular concentrations of the respective AA, assuming a single time point measurement is reflective of the steady state.

In the current study, the serum 3-MH concentrations, as an indicator of protein breakdown (Harris and Milne, 1981), and the 3-MH:creatinine ratio (a measure of the fractional catabolic rate of myofibrillar protein) did not differ between groups but were elevated on $\mathrm{d}$ +3 in both groups and decreased thereafter. This may reflect an increased muscle protein degradation around parturition because 3-MH stems from the methylation of His residues in actin and in myosin (Asatoor and Armstrong, 1967; Hardy and Perry, 1969) and is released into the circulation during muscle degradation. The onset as well as the duration and extent of protein and energy mobilization from body reserves during the transition period are highly variable in dairy cows (van der Drift et al., 2012). According to plasma 3-MH concentrations and muscle thickness, mobilization of protein starts antepartum, even before the onset of lipid mobilization in most cows (van der Drift et al., 2012), and continues to 3 to 5 wk after parturition (Zurek et al., 1995; Doepel et al., 2002; van der Drift et al., 2012). Pires et al. (2013) reported a trend for lower plasma creatinine and a greater $3-\mathrm{MH}$ :creatinine ratio in cows with low BCS $(\leq 2.5)$ compared with cows with medium (2.75-3.5) and high $(\geq 3.75)$ BCS, pointing to less muscle mass but more intense mobilization of muscle protein in lean cows. The lack of differences in the plasma creatinine and 3-MH:creatinine ratio of medium- and high-BCS cows in the study reported by Pires et al. (2013) is in agreement with our observations in the present study. The cellular regulation of skeletal muscle proteolysis in dairy cows in response to negative energy and protein balance is not well described. However, it is well documented that the UPS plays a major role in regulating skeletal muscle proteolysis (Attaix et al., 1994). The proteins targeted for degradation by the UPS are first tagged with ubiquitin, mediated by the ATP-dependent E1 class of ubiquitin-activating enzymes (Glickman and Ciechanover, 2002; Nandi et al., 2006). Once activated, ubiquitin is transferred to a member of the E2 class of ubiquitin-conjugating enzymes and is finally conjugated to the target protein with a specific E3 class of ubiquitin ligases. This tagged protein is then proteolyzed by the proteasome enzyme complex (Glickman and Ciechanover, 2002; Nandi et al., 2006). In the current study, the mRNA abundance of $U B A 1, U B E 2 G 1$, and atrogin- 1 on $\mathrm{d}+21$ was greater in HBCS cows than in NBCS cows. These findings may indicate upregulation of the UPS system at the mRNA level, which was accompanied by lower DMI and more pronounced NEB. The 2 major muscle-specific E3 ubiquitin ligases, MuRF-1 and atrogin-1, are specific indicators for the activation of the UPS, and their abundance is crucial for skeletal muscle degradation in a catabolic state (Bodine et al., 2001; Foletta et al., 2011; Gomes et al., 2012). However, our data showed that besides $U B A 1$ and $U B E 2 G 1$, only atrogin-1 mRNA was affected by BCS on $d+21$ and was more abundant in HBCS cows than in NBCS cows. For MuRF1, the 
mRNA abundance was greater in HBCS cows on $d+3$, pointing to the differential response of the 2 ligases to the metabolic changes occurring during early lactation as influenced by overconditioning. It seems that the differential expression of these ligases in certain experimental conditions is not uncommon, as reported previously in mice (Frost et al., 2007; Yoshida et al., 2010), neonatal pigs (Suryawan and Davis, 2014), and neonatal calves (Sadri et al., 2017). It is known that the downstream substrates of MuRF-1 and atrogin-1 are not similar and, besides degradation, they are involved in regulating other physiological functions (Foletta et al., 2011). The myogenic transcription factors MyoD and myogenin are known as protein target substrates for atrogin-1, and hence atrogin-1 may play a role in regulating muscle size (Foletta et al., 2011). In contrast to atrogin-1, MuRF-1 preferentially interacts with and degrades myofibrillar protein components such as titin (Centner et al., 2001) and myosin light chain 1 and 2 (Cohen et al., 2009). Furthermore, atrogin-1 has been proposed to regulate the substrate targets and thus affect muscle protein synthesis and muscle growth, whereas MuRF-1 may play a role in the control of protein degradation and might contribute to skeletal muscle metabolism.

Interestingly, in the current study, upregulation of atrogin-1 coincided with the greater abundance of $m T O R$ and $4 E B P 1 \mathrm{mRNA}$. The underlying molecular mechanism responsible for the upregulation of key components of mTOR (a major regulator of protein synthesis) in HBCS cows on d +21 , despite greater atrogin-1 mRNA abundance, remains to be clarified. However, this might reflect a simultaneous activation of anabolic and catabolic processes resulting in greater protein turnover. Two proteolytic systems, the UPS and lysosomal system, are mainly responsible for the degradation of proteins and organelles, both working in tandem (Ciechanover, 2005). When UPS is stimulated (as reflected by the increase of atrogin- 1 mRNA abundance in the current study), the proteolytic system, regulated by lysosomal degradation, is also increased (Lilienbaum, 2013). Interestingly, a physical association has been reported between mTOR and lysosomes that seem to play a critical role in AA-mediated mTOR activation (Sancak et al., 2010; Narita and Inoki, 2012). In response to increased autophagy, the Ragulator-Rag complexes mediate AA-mediated mTOR recruitment to the lysosome surface. As a consequence, the formation of an mTOR-autophagy spatial coupling compartment may allow activation of mTOR and autophagy in a mutually reinforcing manner and thus propose a mechanism for the simultaneous activation of anabolic and catabolic processes (Sancak et al., 2010; Narita and
Inoki, 2012). Taken together, overconditioning around calving was associated with the enhanced expression of the 2 major muscle-specific ligases. As a consequence, proteolysis might have been stimulated and the differential expression of $M u R F 1$ and atrogin-1, which coincided with the greater mRNA abundance of key components of mTOR signaling (in case of atrogin-1), could be interpreted as an adaptive response of protein metabolism that helps to prevent excessive loss of skeletal muscle mass during early lactation in these cows. As reported previously from this experiment (Schuh et al., 2019), the circulating NEFA concentrations in the HBCS cows increased earlier and to greater levels than those in the NBCS cows, pointing to more intensive body fat mobilization in the HBCS cows. Replenishment of tricarboxylic acid (TCA) cycle intermediates through other metabolites than propionate, such as lactate and gluconeogenic AA, becomes more important when endogenous glucose demand exceeds propionate supply to offset the loss of TCA cycle intermediates from mitochondria over time (Owen et al., 2002; White, 2015). Thus, it is also likely that a greater protein turnover in the muscle of HBCS cows plays a role in supporting glucose and lipid oxidation, a process known as anaplerosis, which seems to be more important than its direct contribution to energy supply (Owen et al., 2002; White, 2015). A greater abundance of $B C K D H A$ mRNA, participating in the conversion of branchedchain AA to propionyl-CoA, in the subcutaneous adipose tissue of HBCS cows compared with that of NBCS cows (our unpublished data) may further indicate a higher anaplerosis and an increased use of these AA in the peripheral tissues of HBCS cows. In support of this, Schäff et al. (2012) reported that more intensive body fat mobilization during the postpartum period in dairy cows was associated with a lower DMI and increased anaplerosis, TCA cycling, and mitochondrial oxidation of acetyl-CoA. Together, our data indicate that intensive body fat mobilization of HBCS cows during the postpartum period may lead to augmenting nutrient catabolism for anaplerosis and mitochondrial respiration (Schäff et al., 2012), providing a molecular link between muscle protein metabolism and lipid oxidation, known as anaplerosis.

\section{CONCLUSIONS}

Cows calving with high BCS were metabolically challenged during early lactation, associated with the greater mRNA abundance of $M u R F 1$ (on $\mathrm{d}+3$ ) as well as UBA1, UBE2G1, and atrogin-1 (on $\mathrm{d}+21$ ), which may be related to upregulation of the UPS and, consequently, stimulation of protein degradation in 
the muscle tissue. The observed upregulation of key components of mTOR in HBCS cows on $\mathrm{d}+21$ despite the increase in atrogin-1 mRNA may point to simultaneous activation of anabolic and catabolic processes, probably serving as an adaptive response of protein metabolism that may prevent excessive loss of skeletal muscle mass during early lactation. Further studies that address changes in body composition, nitrogen balance, and whole-body and skeletal muscle protein turnover, in combination with expression and activity patterns of intracellular regulators of muscle mass, are required to unravel the cellular mechanisms contributing to the regulation of skeletal muscle proteolysis in high- versus normal-conditioned cows.

\section{ACKNOWLEDGMENTS}

K. Schuh was the recipient of a scholarship from the H. Wilhelm Schaumann Foundation (Hamburg, Germany). The study would not have been possible without the Educational and Research Centre for Animal Husbandry, Hofgut Neumuehle (Muenchweiler an der Alsenz, Germany), which made the cows available and supported the animal trial with their staff. Special gratitude is expressed to Isabella Israel and Inga Hofs (Institute of Animal Science, Physiology and Hygiene Unit, University of Bonn, Germany) for their excellent technical assistance.

\section{REFERENCES}

Asatoor, A. M., and M. D. Armstrong. 1967. 3-Methylhistidine, a component of actin. Biochem. Biophys. Res. Commun. 26:168-174.

Attaix, D., D. Taillandier, S. Temparis, D. Larbaud, E. Aurousseau, L. Combaret, and L. Voisin. 1994. Regulation of ATP-ubiquitindependent proteolysis in muscle wasting. Reprod. Nutr. Dev. 34:583-597.

Bell, A. W., W. S. Burhans, and T. R. Overton. 2000. Protein nutrition in late pregnancy, maternal protein reserves and lactation performance in dairy cows. Proc. Nutr. Soc. 59:119-126.

Bernabucci, U., B. Ronchi, N. Lacetera, and A. Nardone. 2005. Influence of body condition score on relationships between metabolic status and oxidative stress in periparturient dairy cows. J. Dairy Sci. 88:2017-2026.

Bodine, S. C., E. Latres, S. Baumhueter, V. K. Lai, L. Nunez, B. A Clarke, W. T. Poueymirou, F. J. Panaro, E. Na, K. Dharmarajan, Z. Q. Pan, D. M. Valenzuela, T. M. DeChiara, T. N. Stitt, G. D Yancopoulos, and D. J. Glass. 2001. Identification of ubiquitin ligases required for skeletal muscle atrophy. Science 294:1704-1708.

Bustin, S. A., V. Benes, J. A. Garson, J. Hellemans, J. Huggett, M. Kubista, R. Mueller, T. Nolan, M. W. Pfaffl, G. L. Shipley, J. Vandesompele, and C. T. Wittwer. 2009. The MIQE guidelinesMinimum information for publication of quantitative real-time PCR experiments. Clin. Chem. 55:611-622. https://doi.org/10 1373 /clinchem.2008.112797.

Castro, J. J., S. I. Arriola Apelo, J. A. D. R. N. Appuhamy, and M. D. Hanigan. 2016. Development of a model describing regulation of casein synthesis by the mammalian target of rapamycin (mTOR) signaling pathway in response to insulin, amino acids, and acetate. J. Dairy Sci. 99:6714-6736. https://doi.org/10.3168/ jds.2015-10591.

Centner, T., J. Yano, E. Kimura, A. S. McElhinny, K. Pelin, C. C. Witt, M.-L. Bang, K. Trombitas, H. Granzier, C. C. Gregorio, H. Sorimachi, and S. Labeit. 2001. Identification of muscle specific ring finger proteins as potential regulators of the titin kinase domain. J. Mol. Biol. 306:717-726. https://doi.org/10.1006/jmbi .2001 .4448 .

Chibisa, G. E., G. N. Gozho, A. G. Van Kessel, A. A. Olkowski, and T. Mutsvangwa. 2008. Effects of peripartum propylene glycol supplementation on nitrogen metabolism, body composition, and gene expression for the major protein degradation pathways in skeletal muscle in dairy cows. J. Dairy Sci. 91:3512-3527. https://doi.org/ 10.3168/jds.2007-0920.

Ciechanover, A. 2005. Proteolysis: From the lysosome to ubiquitin and the proteasome. Nat. Rev. Mol. Cell Biol. 6:79-87.

Cohen, S., J. J. Brault, S. P. Gygi, D. J. Glass, D. M. Valenzuela C. Gartner, E. Latres, and A. L. Goldberg. 2009. During muscle atrophy, thick, but not thin, filament components are degraded by MuRF1-dependent ubiquitylation. J. Cell Biol. 185:1083-1095.

David, Y., T. Ziv, A. Admon, and A. Navon. 2010. The E2 ubiquitinconjugating enzymes direct polyubiquitination to preferred lysines. J. Biol. Chem. 285:8595-8604. https://doi.org/10.1074/jbc.M109 .089003 .

de Vries, M. J., and R. F. Veerkamp. 2000. Energy balance of dairy cattle in relation to milk production variables and fertility. J. Dairy Sci. 83:62-69. https://doi.org/10.3168/jds.S0022-0302(00)74856-9.

Doepel, L., H. Lapierre, and J. J. Kennelly. 2002. Peripartum performance and metabolism of dairy cows in response to prepartum energy and protein intake. J. Dairy Sci. 85:2315-2334.

Dong, X., Z. Zhou, B. Saremi, A. Helmbrecht, Z. Wang, and J. J. Loor. 2018. Varying the ratio of Lys:Met while maintaining the ratios of Thr:Phe, Lys:Thr, Lys:His, and Lys:Val alters mammary cellular metabolites, mammalian target of rapamycin signaling, and gene transcription. J. Dairy Sci. 101:1708-1718. https://doi.org/ 10.3168/jds.2017-13351.

Drackley, J. K. 1999. Biology of dairy cows during the transition period: The final frontier? J. Dairy Sci. 82:2259-2273.

Edmonson, A. J., I. J. Lean, L. D. Weaver, T. Farver, and G. Webster 1989. A body condition scoring chart for Holstein dairy cows. J. Dairy Sci. 72:68-78.

EMA (European Medicines Agency). 2011. Guideline on bioanalytical method validation. Accessed Aug. 23, 2019. https://www .ema.europa.eu/en/documents/scientific-guideline/guideline -bioanalytical-method-validation_en.pdf.

Foletta, V. C., L. J. White, A. E. Larsen, B. Léger, and A. P. Russell 2011. The role and regulation of MAFbx/atrogin-1 and MuRF1 in skeletal muscle atrophy. Pflugers Arch. 461:325-335. https://doi .org/10.1007/s00424-010-0919-9.

Franch, H. A., and S. R. Price. 2005. Molecular signaling pathways regulating muscle proteolysis during atrophy. Curr. Opin. Clin. Nutr. Metab. Care 8:271-275. https://doi.org/10.1097/01.mco .0000165005 .01331 .45 .

Frost, R. A., G. J. Nystrom, L. S. Jefferson, and C. H. Lang. 2007. Hormone, cytokine, and nutritional regulation of sepsis-induced increases in atrogin-1 and MuRF1 in skeletal muscle. Am. J. Physiol. Endocrinol. Metab. 292:E501-E512.

Fürst, P., L. Pollack, T. A. Graser, H. Godel, and P. Stehle. 1990 Appraisal of four pre-column derivatization methods for the highperformance liquid chromatographic determination of free amino acids in biological materials. J. Chromatogr. 499:557-569.

GfE (German Society of Nutrition Physiology). 2001. Empfehlungen zur Energie- und Nährstoffversorgung der Milchkühe und Aufzuchtrinder [Recommended energy and nutrient supply for dairy cows and heifers]. Ausschuss für Bedarfsnormen der Gesellschaft für Ernährungsphysiologie No. 8. DLG Verlag, Frankfurt am Main, Germany.

GfE (German Society of Nutrition Physiology). 2009. New equation for predicting metabolizable energy of compound feeds for cattle. 
Pages 143-146 in Proc. Society of Nutrition Physiology. DLG-Verlag, Frankfurt am Main, Germany.

Glickman, M. H., and A. Ciechanover. 2002. The ubiquitin-proteasome proteolytic pathway: Destruction for the sake of construction. Physiol. Rev. 82:373-428.

Gomes, A. V., D. S. Waddell, R. Siu, M. Stein, S. Dewey, J. D. Furlow, and S. C. Bodine. 2012. Upregulation of proteasome activity in muscle RING finger 1-null mice following denervation. FASEB J. 26:2986-2999. https://doi.org/10.1096/fj.12-204495.

Greenwood, S. L., T. C. Wright, N. G. Purdie, J. Doelman, J. P. Cant, and B. W. McBride. 2009. Lactation induces upregulation of the ubiquitin-mediated proteolytic pathway in skeletal muscle of dairy cows but does not alter hepatic expression. Can. J. Anim. Sci. 89:309-313. https://doi.org/10.4141/CJAS08125.

Hardy, M. F., and S. V. Perry. 1969. In vitro methylation of muscle proteins. Nature 223:300-302.

Harris, C. I., and G. Milne. 1981. The urinary excretion of N-taumethyl histidine by cattle: Validation as an index of muscle protein breakdown. Br. J. Nutr. 45:411-422.

Hellemans, J., G. Mortier, A. De Paepe, F. Speleman, and J. Vandesompele. 2007. qBase relative quantification framework and software for management and automated analysis of real-time quantitative PCR data. Genome Biol. 8:R19. https://doi.org/10.1186/ gb-2007-8-2-r19.

Heuer, C., Y. H. Schukken, and P. Dobbelaar. 1999. Postpartum body condition score and results from the first test day milk as predictors of disease, fertility, yield, and culling in commercial dairy herds. J. Dairy Sci. 82:295-304.

Holtenius, K., S. Agenas, C. Delavaud, and Y. Chilliard. 2003. Effects of feeding intensity during the dry period. 2. Metabolic and hormonal responses. J. Dairy Sci. 86:883-891.

Jacinto, E., R. Loewith, A. Schmidt, S. Lin, M. A. Ruegg, A. Hall, and M. N. Hall. 2004. Mammalian TOR complex 2 controls the actin cytoskeleton and is rapamycin insensitive. Nat. Cell Biol. 6:1122-1128. https://doi.org/10.1038/ncb1183.

Kessel, S., M. Stroehl, H. H. Meyer, S. Hiss, H. Sauerwein, F. J. Schwarz, and R. M. Bruckmaier. 2008. Individual variability in physiological adaptation to metabolic stress during early lactation in dairy cows kept under equal conditions. J. Anim. Sci. 86:29032912. https://doi.org/10.2527/jas.2008-1016.

Komaragiri, M. V. S., D. P. Casper, and R. A. Erdman. 1998. Factors affecting body tissue mobilization in early lactation dairy cows. 2 . Effect of dietary fat on mobilization of body fat and protein. J. Dairy Sci. 81:169-175.

Komaragiri, M. V. S., and R. A. Erdman. 1997. Factors affecting body tissue mobilization in early lactation dairy cows. 1. Effect of dietary protein on mobilization of body fat and protein. J. Dairy Sci. 80:929-937.

Kuhla, B., G. Nürnberg, D. Albrecht, S. Görs, H. M. Hammon, and C. C. Metges. 2011. Involvement of skeletal muscle protein, glycogen, and fat metabolism in the adaptation on early lactation dairy cows. J. Proteome Res. 10:4252-4262. https://doi.org/10.1021/ pr200425h

Larsen, M., and N. B. Kristensen. 2013. Precursors for liver gluconeogenesis in periparturient dairy cows. Animal 7:1640-1650. https:// doi.org/10.1017/S1751731113001171.

Lilienbaum, A. 2013. Relationship between the proteasomal system and autophagy. Int. J. Biochem. Mol. Biol. 4:1-26.

Maeda, Y., H. Ohtsuka, and M. Oikawa. 2012. Effect of the periparturient period on blood free amino acid concentration in dairy cows/ healthy cows. J. Vet. Med. Anim. Health 4:124-129. https://doi .org/10.5897/JVMAH11.042.

Mann, S., A. Abuelo, D. V. Nydam, F. A. Leal Yepes, T. R. Overton, and J. J. Wakshlag. 2016. Insulin signaling and skeletal muscle atrophy and autophagy in transition dairy cows either overfed energy or fed a controlled energy diet prepartum. J. Comp. Physiol. B 186:513-525. https://doi.org/10.1007/s00360-016-0969-1.

Mann, S., F. A. Yepes, T. R. Overton, J. J. Wakshlag, A. L. Lock, C. M. Ryan, and D. V. Nydam. 2015. Dry period plane of energy: Effects on feed intake, energy balance, milk production, and composition in transition dairy cows. J. Dairy Sci. 98:3366-3382.
Meijer, G. A., J. Van der Meulen, J. G. Bakker, C. J. Van der Koelen, and A. M. Van Vuuren. 1995. Free amino acids in plasma and muscle of high yielding dairy cows in early lactation. J. Dairy Sci. 78:1131-1141.

Nandi, D., P. Tahiliani, A. Kumar, and D. Chandu. 2006. The ubiquitin-proteasome system. J. Biosci. 31:137-155.

Narita, M., and K. Inoki. 2012. Rags connect mTOR and autophagy. Small GTPases 3:111-114. https://doi.org/10.4161/sgtp.19422.

Naumann, C., and R. Bassler. 2004. Die chemische Untersuchung von Futtermitteln. VDLUFA-Verlag, Darmstadt, Germany.

Owen, O. E., S. C. Kalhan, and R. W. Hanson. 2002. The key role of anaplerosis and cataplerosis for citric acid cycle function. J. Biol. Chem. 277:30409-30412.

Phillips, G. J., T. L. Citron, J. S. Sage, K. A. Cummins, M. J. Cecava, and J. P. McNamara. 2003. Adaptations in body muscle and fat in transition dairy cattle fed differing amounts of protein and Met hydroxy analog. J. Dairy Sci. 86:3634-3647. https://doi.org/ 10.3168/jds.S0022-0302(03)73969-1.

Pires, J. A. A., C. Delavaud, Y. Faulconnier, D. Pomiès, and Y. Chilliard. 2013. Effects of body condition score at calving on indicators of fat and protein mobilization of periparturient Holstein-Friesian cows. J. Dairy Sci. 96:6423-6439. https://doi.org/10.3168/jds.2013 $-6801$.

Plaizier, J. C., J. P. Walton, A. Martin, T. Duffield, R. Bagg, P. Dick, and B. W. McBride. 2000. Short communication: Effects of monensin on 3-methylhistidine excretion in transition dairy cows. J. Dairy Sci. 83:2810-2812. https://doi.org/10.3168/jds.S0022 $-0302(00) 75179-4$.

Roche, J. R., N. C. Friggens, J. K. Kay, M. W. Fisher, K. J. Stafford, and D. P. Berry. 2009. Invited review: Body condition score and its association with dairy cow productivity, health, and welfare. J. Dairy Sci. 92:5769-5801. https://doi.org/10.3168/jds.2009-2431.

Rock, K. L., C. Gramm, L. Rothstein, K. Clark, R. Stein, L. Dick, D. Hwang, and A. L. Goldberg. 1994. Inhibitors of the proteasome block the degradation of most cell proteins and the generation of peptides presented on MHC class 1 molecules. Cell 78:761-771. https://doi.org/10.1016/s0092-8674(94)90462-6.

Rukkwamsuk, T., T. A. Kruip, and T. Wensing. 1999. Relationship between overfeeding and overconditioning in the dry period and the problems of high producing dairy cows during the postparturient period. Vet. Q. 21:71-77.

Sadri, H., F. Giallongo, A. N. Hristov, J. Werner, C. H. Lang, C. Parys, B. Saremi, and H. Sauerwein. 2016. Effects of slow-release urea and rumen-protected Met and His on mammalian target of rapamycin (mTOR) signaling and ubiquitin proteasome-related gene expression in skeletal muscle of dairy cows. J. Dairy Sci. 99:6702-6713. https://doi.org/10.3168/jds.2015-10673.

Sadri, H., J. Steinhoff-Wagner, H. M. Hammon, R. M. Bruckmaier, S. Görs, and H. Sauerwein. 2017. Mammalian target of rapamycin signaling and ubiquitin proteasome-related gene expression in 3 different skeletal muscles of colostrum- versus formula-fed calves. J. Dairy Sci. 100:9428-9441. https://doi.org/10.3168/jds.2017 $-12857$.

Samman, S., B. Crossett, M. Somers, K. J. Bell, N. T. Lai, D. R Sullivan, and P. Petocz. 2014. Metabolic profiling of plasma amino acids shows that His increases following the consumption of pork. Diabetes Metab. Syndr. Obes. 7:203-210. https://doi.org/10 .2147/DMSO.S60382.

Sancak, Y., L. Bar-Peled, R. Zoncu, A. L. Markhard, S. Nada, and D. M. Sabatini. 2010. Ragulator-Rag complex targets mTORC1 to the lysosomal surface and is necessary for its activation by amino acids. Cell 141:290-303.

Saremi, B., A. Al-Dawood, S. Winand, U. Müller, J. Pappritz, D. von Soosten, J. Rehage, S. Dänicke, S. Häussler, M. Mielenz, and H. Sauerwein. 2012. Bovine haptoglobin as an adipokine: Serum concentrations and tissue expression in dairy cows receiving a conjugated linoleic acids supplement throughout lactation. Vet. Immunol. Immunopathol. 146:201-211. https://doi.org/10.1016/j .vetimm.2012.03.011.

Schäff, C., S. Börner, S. Hacke, U. Kautzsch, D. Albrecht, H. Hammon, M. Röntgen, and B. Kuhla. 2012. Increased anaplerosis, 
TCA cycling, and oxidative phosphorylation in the liver of dairy cows with intensive body fat mobilization during early lactation. J. Proteome Res. 11:5503-5514.

Schuh, K., H. Sadri, S. Häussler, C. Koch, J. Frahm, S. Dänicke, G. Dusel, and H. Sauerwein. 2019. Comparison of performance and metabolism from late pregnancy to early lactation in dairy cows with elevated v. normal body condition at dry-off. Animal 13:1478-1488. https://doi.org/10.1017/S1751731118003385.

Schulman, B. A., and J. W. Harper. 2009. Ubiquitin-like protein activation by E1 enzymes: The apex for downstream signaling pathways. Nat. Rev. Mol. Cell Biol. 10:319-331. https://doi.org/10 $.1038 / \mathrm{nrm} 2673$.

Schulz, K., J. Frahm, U. Meyer, S. Kersten, D. Reiche, J. Rehage, and S. Danicke. 2014. Effects of prepartal body condition score and peripartal energy supply of dairy cows on postpartal lipolysis, energy balance and ketogenesis: An animal model to investigate subclinical ketosis. J. Dairy Res. 81:257-266.

Sheldon, I. M., S. E. Owens, and M. L. Turner. 2017. Innate immunity and the sensing of infection, damage and danger in the female genital tract. J. Reprod. Immunol. 119:67-73. https://doi.org/10 $.1016 /$ j.jri.2016.07.002

Suryawan, A., and T. A. Davis. 2014. Regulation of protein degradation pathways by amino acids and insulin in skeletal muscle of neonatal pigs. J. Anim. Sci. Biotechnol. 5:8.

van der Drift, S. G., M. Houwelling, J. T. Schonwellie, A. G. Tielens, and R. Jorritsma. 2012. Protein and fat mobilization and associa- tions with serum $\beta$-hydroxybutyrate concentrations in dairy cows. J. Dairy Sci. 95:4911-4920. https://doi.org/10.3168/jds.2011-4771.

Verbeke, R., E. Rocts, and G. Peeters. 1972. Variations in the concentrations of free amino acids in the plasma of the dairy cow at parturition. J. Dairy Res. 39:355-364.

White, H. M. 2015. The role of TCA cycle anaplerosis in ketosis and fatty liver in periparturient dairy cows. Animals (Basel) 5:793-802.

Yoshida, T., L. Semprun-Prieto, S. Sukhanov, and P. Delafontaine. 2010. IGF-1 prevents ANG II-induced skeletal muscle atrophy via Akt- and Foxo-dependent inhibition of the ubiquitin ligase atrogin-1 expression. Am. J. Physiol. Heart Circ. Physiol. 298:H1565H1570

Zukunft, S., C. Prehn, C. Röhring, G. Möller, M. Hrabě de Angelis, J. Adamski, and J. Tokarz. 2018. High-throughput extraction and quantification method for targeted metabolomics in murine tissues. Metabolomics 14:18. https://doi.org/10.1007/s11306-017 $-1312-\mathrm{x}$.

Zukunft, S., M. Sorgenfrei, C. Prehn, G. Möller, and J. Adamski. 2013. Targeted metabolomics of dried blood spot extracts. Chromatographia 76:1295-1305. https://doi.org/10.1007/s10337-013-2429-3.

Zurek, E., G. R. Foxcroft, and J. J. Kennelly. 1995. Metabolic status and interval to first ovulation in postpartum dairy cows. J. Dairy Sci. 78:1909-1920. 